6-30-2020

\title{
A Multi-scale Approach for Simulating Tidal Marsh Evolution
}

\author{
Karinna Nunez \\ Virginia Institute of Marine Science \\ Yinglong J. Zhang \\ Virginia Institute of Marine Science \\ Julie Herman \\ Virginia Institute of Marine Science \\ W. G. Reay \\ Virginia Institute of Marine Science \\ Carl Hershner \\ Virginia Institute of Marine Science
}

Follow this and additional works at: https://scholarworks.wm.edu/vimsarticles

Part of the Terrestrial and Aquatic Ecology Commons

\section{Recommended Citation}

Nunez, Karinna; Zhang, Yinglong J.; Herman, Julie; Reay, W. G.; and Hershner, Carl, A Multi-scale Approach for Simulating Tidal Marsh Evolution (2020). Ocean Dynamics.

doi: 10.1007/s10236-020-01380-6

This Article is brought to you for free and open access by the Virginia Institute of Marine Science at W\&M ScholarWorks. It has been accepted for inclusion in VIMS Articles by an authorized administrator of W\&M ScholarWorks. For more information, please contact scholarworks@wm.edu. 


\section{A Multi-scale Approach for Simulating Tidal Marsh Evolution}

Karinna Nunez $^{\mathrm{a} 1}$, Yinglong J. Zhang ${ }^{\mathrm{a}}$, Julie Herman ${ }^{\mathrm{a}}$, William Reay ${ }^{\mathrm{a}}$, Carlton Hershner ${ }^{\mathrm{a}}$

${ }^{\text {a }}$ Virginia Institute of Marine Science, William \& Mary, Gloucester Point, Virginia, USA

${ }^{1}$ Corresponding author; e-mail: karinna@ vims.edu; phone: (804) 684-7273; fax: (804) 684-7179.

\section{Acknowledgements}

The authors would like to especially thank Eduardo Miles, Alex Demeo, Kory Angstadt, and Dave Stanhope for their support with field-work activities. We would also like to thank the anonymous reviewers whose comments helped improve the manuscript.

This study was supported by the National Oceanic and Atmospheric Administration (grant number NA17NOS4730142), the United States Environmental Protection Agency (grant number CD96347001-0), the National Science Foundation (grant number 1600131), and the Chesapeake Bay National Estuarine Research Reserve's Rouse-Bottom Fellowship. This paper is Contribution No. 3870 of the Virginia Institute of Marine Science, William \& Mary.

Some simulations used in this paper were conducted using the following computational facilities: (1) SciClone at William \& Mary which were provided with assistance from the National Science Foundation, the Virginia Port Authority, Virginia's Commonwealth Technology Research Fund, and the Office of Naval Research; (2) the Extreme Science and Engineering Discovery Environment (XSEDE; Grant TG-OCE130032), which is supported by National Science Foundation grant number OCI-1053575; (3) the NASA High-End Computing (HEC) Program through the NASA Advanced Supercomputing (NAS) Division at Ames Research Center. 


\section{Abstract}

This study presents a new approach to modeling marsh evolution. The Tidal Marsh Model (TMM) has been developed as a module within the SCHISM framework (Semi-implicit Cross-scale Hydroscience Integrated System Model). Some unique features of the TMM are dynamic rates, crossscale simulations, and incorporation of anthropogenic stressors, which allow it to overcome many limitations that current marsh models possess. To evaluate model performance, the TMM was applied in Carter Creek and Taskinas Creek within the York River system (Virginia, USA). We assessed model outputs against field observations focusing on two main aspects: marsh boundary evolution and distribution of marsh sediments. Marsh migration is captured with an accuracy of $81 \%$ in Carter Creek, and an accuracy of $78 \%$ in Taskinas Creek. Different statistical descriptors were used to evaluate the model's ability to reproduce the distribution of observed marsh sediment fractions. Results in both study areas show a satisfactory agreement between sediment model outputs and field observations. This innovative modeling approach will help close some critical knowledge gaps in the current understanding of the system dynamics and allow better implementation of management actions to preserve these ecosystems and their services.

Keywords: marsh evolution model, sea-level rise, cross-scale simulation, unstructured grid, SCHISM.

\section{Introduction}

Marshes perform multiple ecological functions and have special characteristics that make them important and valuable natural resources. They provide habitat for many organisms; offer storm surge protection as well as upland erosion protection, given their capacity to attenuate wave energy; and play an important role in water quality, due to their ability to filter several pollutants; and trap sediments from both aquatic and terrestrial inputs (Fisher and Acreman 2004; Mitsch and Gosselink 2007).

Marsh habitats are experiencing growing threats from sea-level rise (SLR) and recurrent flooding due to climate change. With current SLR rates on the order of 5-6 mm/yr and accelerating (Boon and Mitchell 2015), the Chesapeake Bay region is one of the most vulnerable areas in the U.S. (Glick et al. 2008). Higher levels of relative SLR can be attributed to a combination of increased 
absolute sea-level rise and land subsidence in this region, mainly due to glacial isostatic processes and local excessive groundwater withdrawal (Eggleston and Pope 2013). In addition, recent studies (e.g. Sallenger et al. 2012; Ezer et al. 2013; Rahmstorf et al. 2015) have implicated a relatively recent (mid2000's) weakening and path shift of the Gulf Stream as a contributing factor to SLR along the midAtlantic (Ezer et al. 2013; Hansen et al. 2016). The temporal effect of this change in circulation pattern is still unknown. The accelerated rates of SLR observed along the mid-Atlantic coast have raised concerns over tidal marsh sustainability within the Chesapeake Bay region (Glick et al. 2008; Mitchell et al. 2017). It is crucial to increase understanding and improve predictions of how changes in sea level will impact coastal marshes across geographic scales to inform policy, localized protection, and restoration aimed at sustaining these habitats in the near and long-term. It is well established that tidal marshes can respond to SLR (e.g., Morris et al. 2002; Kirwan and Murphy 2007; Raposa et al. 2017; Horton et al. 2018) through vertical accretion and horizontal migration (Figure 1). Inorganic sediment sources to the marsh include bank erosion, sediments from upland runoff, and tidally delivered sediments. In addition, marshes vertically accrete via accumulation of below and above ground plant biomass.

Different geomorphic settings present different hydrodynamics, sediment supplies, and marsh plant communities. For that reason, the response of marshes to changing sea level is expected to vary by geomorphic settings (Cahoon and Guntenspergen 2010; Kolker et al. 2010; Jørgensen and Fath 2011a). It is important to understand how local conditions influence marshes, in particular how temporal and spatial variations in sediment supply, deposition, and surface erosion affect the sustainability of these habitats. Because these factors are quite variable in many coastal and estuarine systems, the development of dynamic simulations of marsh evolution at fine spatial resolutions is important for informed management of current and future marsh resources.

Due to the increased need to assess tidal marsh vulnerability in the light of changing environments, different models have been developed to predict marsh spatial extent and future 
93

94

95

distribution, as well as to assist resource managers and habitat restoration practitioners in their decision-making process. Current models are constrained by the limitations of the two commonly used modeling approaches: landscape-scale models and site-specific models. Landscape-scale models (e.g. Sea Level Affecting Marshes Model, SLAMM (Clough et al. 2010)) often use fixed rates (e.g. erosion rates) during the entire simulation. They simulate general trends over large areas, but typically at a relatively coarse resolution. For that reason, these types of model are not suitable for site-specific research and management uses because scaling down the results to local levels is not feasible, thereby limiting their accuracy and usefulness to local applications. Conversely, site-specific models (e.g. Marsh Evolution Model, MEM (Morris et al. 2002)) are more mechanistic. They are employed to simulate responses for a specific site with a particular set of conditions and settings. Like the landscape models, site-specific models have scaling limitations as well. Using results from an individual site to make long-term projections at larger spatial extents is challenging due to the broad range of geomorphic settings across landscapes (Titus et al. 2009). Moreover, shoreline structures that interfere with the natural migration of wetlands as a response to sea-level rise are not considered in these approaches.

In recent years, several studies that used landscape-scale models incorporated different dynamic approaches to particularly evaluate marsh vertical accretion. For example, Clough et al. (2016) used SLAMM to evaluate the potential effect of SLR on the marshes along the New York coast using a $5 \mathrm{~m}$ horizontal resolution. To improve model results, the authors combined SLAMM data with a mechanistic approach to estimate marsh vertical accretion by applying MEM (at a site-specific level). In addition, Alizad et al. (2016) developed and applied a spatially-explicit model called Hydro-MEM in the Timucuan salt marsh, located along the lower St. Johns River (Florida). This integrated approach combines spatial dynamics of salt marshes and predicts the impacts of possible future sea-level conditions. Hydro-MEM is a zero-dimensional model coupled with the hydrodynamic model ADCIRC (ADvanced CIRCulation Model) (Luettich and Westerink 2006) to create a dynamic 2-dimensional 
marsh model. Even though the approach refines the simulation of some processes, the resolution in that study is very limited due to the inherent stability constraints in the circulation model (Zhang et al. 2019). Moreover, several numerical models have been proposed to determine salt marsh survival under different scenarios of SLR (e.g., Temmerman et al. 2003b; Van Proosdij et al. 2006; D'Alpaos et al. 2007a; Mariotti and Fagherazzi 2010; Kirwan et al. 2016). These models attempt to quantify the evolution of salt marshes under different physical and ecological drivers. In many of these models, the sediment transport dynamics of salt marsh evolution are highly simplified, and only represent a starting point for the system. Even though current marsh models are valuable tools to address particular questions, there is still a need to model marshes over a broad geographic extent, but with the spatially explicit resolution currently available only from site-specific marsh evolution studies. been developed based on the SCHISM framework (Semi-implicit Cross-scale Hydroscience Integrated System Model; schism.wiki) (Zhang et al. 2016). SCHISM is a next-generation hydrodynamic modeling system developed for riverine, estuarine, coastal, and ocean applications. Some of the unique features the TMM includes are dynamic rates (most importantly, erosion rates and sediment deposition rates), cross-scale simulations, and incorporation of anthropogenic stressors, which allow it to overcome many limitations that current marsh models present. The initial version of TMM integrates the physical and human components needed to simulate and assess the evolution and persistence of tidal marshes under different SLR scenarios. The TMM effectively interpolates site-specific information across critical conditions, creating the capacity to assess marsh vulnerability under present and potential future conditions. The TMM was tested using a hindcast approach in two different estuarine marsh systems in Chesapeake Bay. Nevertheless, this model has the capability to be exportable (i.e., it can be applied to any marsh system), which considerably increases its applicability. of widespread spatially explicit biological data, we initially assume biological processes to be constant 
and focus on simulating the physical factors and processes that drive marsh evolution, leaving the assessment of the biological processes for our next stage of model development. We attempt to acquire a better spatially explicit understanding of the physical processes related to marsh sustainability based on available physical and anthropogenic data. This insight will allow us to effectively preserve and manage marsh resources and the ecological services that they provide.

\section{Background Information}

accumulation. Both sources of material are important in maintaining a proper marsh platform elevation

for the marsh to persist. Long-term marsh stability requires that the soil surface elevation increases at a

rate similar to the local rate of relative SLR (Reed 1995). Based on Morris et al. (2016), marshes

possess a theoretical maximum vertical accretion rate of $5 \mathrm{~mm} \mathrm{yr}^{-1}$. This is the expected rate from the

combined inputs of inorganics and organics at the highest sediment loading rates. The rate of vertical accretion of $5 \mathrm{~mm} \mathrm{yr}^{-1}$ is comparable to the current SLR rate for the southeastern part of the

(Boon and Mitchell 2015). Morris et al. (2016) showed that contributions from organic production are mainly driven by belowground biomass in tidal salt marshes and the labile organic matter does not add new volume since its production and decay rate are in equilibrium. Nevertheless, the refractory fraction of belowground production contributes to a change in soil volume and can be associated with the production of lignin. The study found that the upper limit for belowground dry weight production of $2500 \mathrm{~g} \cdot \mathrm{m}^{-2} \mathrm{yr}^{-1}$, encompassing $10 \%$ lignin content, provides a theoretical steady-state vertical 
accretion process. Therefore, it is unlikely that marshes can indefinitely survive a higher rate of SLR in the absence of a significant source of inorganic sediment. The supply, deposition, and erosion of sediments vary significantly along estuaries, and appropriate representation of those variations is critical to accurately determine marsh futures.

\subsection{Marsh Horizontal Migration}

Tidal marsh edge stability depends on the health and production of the marsh plants, as well as the effect of wave energy and SLR. Wave energy is the dominant driver of tidal marsh erosion (Fegherazzi et al. 2013). As sea level rises, the time of inundation occurring during the high end of the tidal range increases as well (Ezer and Atkinson 2013). Therefore, this inundation controls the landward extent of these habitats. An increase in inundation at the water's edge of the marsh may erode the marsh edge or cause conversion to mud flats, which are less stable and more erodible than vegetated marshes (Silinski 2015; Rahman 2015). Tidal marshes have the capacity to respond to SLR conditions by moving horizontally to higher elevations, either to adjacent land or into adjacent areas of open water, if they are filled with sediment. In order for marshes to migrate inland, they need to have an adjacent open space in the gradual slope that allows transgression. Migration is truncated in many cases by natural escarpments or steeply sloped shorelines, increased coastal development, or hardened shoreline structures used to stabilize the shoreline and protect upland properties from erosion and SLR (Titus et al. 2009; Gittman et al. 2015; Hill 2015; Enwright et al. 2016). Thus, the presence of shoreline structures (e.g. riprap, bulkhead) is a key feature that needs to be included when modeling the future spatial distribution of tidal marshes. Anthropogenic stressors that interfere with marsh transgressions are crucial parameters that need to be well understood to accurately evaluate marsh response to SLR (Kirwan and Megonigal 2013).

A different process of horizontal migration occurs in marshes behind barrier islands. These systems respond to SLR by migrating toward the mainland when sand is overwashed from the barrier 
island and rolls over onto the back barrier marsh. The overwash deposition allows marshes to increase

194 in elevation and migrate (Finkelstein and Ferland 1987; Fitzgerald et al. 2007; Walters et al. 2014).

195 However, at rapid and high rates of SLR, barrier island migration can outpace marsh migration toward

196 the mainland, yielding a significant marsh loss (Deaton et al. 2017). The interactions between back

197 barrier marshes and barrier islands play a significant role in determining how coastal systems will

198 evolve in the future due to SLR.

\subsection{SCHISM (Semi-implicit Cross-scale Hydroscience Integrated System Model)}

SCHISM (Zhang et al. 2016; schism.wiki) is a derivative product of SELFE v3.1dc (Zhang and

Baptista 2008). SCHISM belongs to a new generation of unstructured-grid models (Figure 2) with

unique features that help overcome the challenges of simulating multi-scale processes. It is a next-

generation hydrodynamic modeling system developed for riverine, estuarine, coastal, and ocean

number of bays, estuaries, and coasts around the world (e.g. Stanev et al. 2017, 2018; Chao et al. 2017;

Yu et al. 2017; Liu et al. 2018; Ye et al. 2018; Guerin et al. 2018; Du et al. 2018) in the context of

general circulation, tsunami and storm-surge inundation, water quality, oil spill, sediment transport, coastal ecology, wave-current interaction, and ice dynamics (e.g. Rodrigues 2009; Burla et al 2010; NTHMP 2012; Pinto 2012; Roland 2012; Azevedo et al. 2014). It is built on a hybrid finiteelement/finite-volume approach using mixed triangular-quadrangular unstructured grids in the horizontal, and a very flexible coordinate system in the vertical, called LSC ${ }^{2}$ (Zhang et al. 2015, 2016).

The application of unstructured grids to coastal ocean processes presents a great advantage for nearshore studies. The superior boundary fitting and local refinement ability of unstructured grids make them ideally suitable for nearshore applications involving complex bathymetry, shoreline 
217 allows a single SCHISM grid to seamlessly morph between full 3D, 2DH, 2DV and 1D cells in 218 different parts of the domain (Zhang et al. 2016).

219 One of the most important strengths of this modeling system is that it is designed for an 220 effective simulation of 3D baroclinic circulation across creek-to-ocean scales (Yu et al. 2017), 221 addressing a wide range of physical and biological processes. These cross-scale interactions of 222 different processes in time and space are possible due to the use of unstructured grids and a semi223 implicit time stepping scheme in the simulations. SCHISM employs an efficient and robust semi224 implicit (i.e., no mode splitting) finite-element/finite-volume method together with an Eulerian225 Lagrangian method to solve the Navier-Stokes equations. As a result, numerical stability is greatly enhanced. SCHISM can enable the use of hyper-resolution ( few meters) with little penalty on the time step, thereby greatly reducing the need to eliminate key physical-chemical-biological processes to efficiently run high resolution model simulations. The finite-element method allows the use of very skewed (typically considered poor quality) elements in the model grid, which will be critical in resolving highly irregular marsh complexes. SCHISM incorporates wetting and drying in a natural way to capture tidal creek swelling and bank overtopping, which is crucial for accurate inter-tidal ecosystem model simulations.

Developing the TMM within this framework allows for unique model capabilities to be naturally incorporated into the simulations. In this initial version of the model, we focused on a $2 \mathrm{D}$ barotropic model configuration due to large uncertainties that exist in some marsh process inputs. For processes as complex as marsh migration, it is important to start from a simple approach, investigate the relative importance of contributing factors, and gradually build up model complexity. While the polymorphism in SCHISM allows efficient simulation of marshes in hybrid 3D-2D mode (Liu et al. 2018), the current 2D model already incorporates most of the physics. 


\section{Methods}

\subsection{Study Area}

The development of the TMM utilized two study sites within the York River system, Virginia, USA (Figure 3a): Carter Creek (Figure 3b), and Taskinas Creek (Figure 3c., a component of the Chesapeake Bay National Estuarine Research Reserve (CBNERR)). The York River is one of the five major tributary systems in the Chesapeake Bay. It is a partially-mixed, microtidal estuary (Sisson et al. 1997) characterized by a main channel flanked by wide shoals. The salinity regimes range from tidal freshwater to polyhaline. Poor water clarity, mainly driven by suspended sediments and phytoplankton, is a persistent problem in the York River (Reay 2009). Near-surface, mid-channel total suspended solids (TSS) concentrations increase with distance upriver, with long-term average TSS concentrations on the order of $<10 \mathrm{mg} \mathrm{L}^{-1}$ in polyhaline regions, $\sim 15 \mathrm{mg} \mathrm{L}^{-1}$ in mesohaline, and $\sim 35 \mathrm{mg} \mathrm{L}^{-1}$ in oligohaline waters (Reay 2009). This tributary has a primary (ETM) and a secondary (STM) estuarine turbidity maximum located approximately $52 \mathrm{~km}$ and $30 \mathrm{~km}$, respectively, from the mouth of the river (Lin and Kuo 2001); the location of the turbidity maximums may change seasonally. TSS concentrations within the ETM and STM are $30-35 \mathrm{mg} \mathrm{L}^{-1}$ in the near surface waters, and 80 - $105 \mathrm{mg}$ $\mathrm{L}^{-1}$ in the near bottom waters (Reay 2009).

The York River system incorporates several geomorphic marsh settings, including fringe, embayed, and extensive marshes (Table 1), distributed along gradients of inundation and salinity. For the TMM development, marshes associated with different geomorphic settings and land uses were selected for simulations. Carter Creek is characterized by a considerable extent of fringe and embayed marshes, while Taskinas Creek is classified as an embayed marsh system. The dominant low marsh plant species for both Carter and Taskinas Creeks is Spartina alterniflora. In high marsh zones, Spartina patens and Distichlis spicata are present. Carter Creek is located on the northern side of the York River, approximately $22 \mathrm{~km}$ from the mouth of the river. Its watershed is characterized mainly by residential and agricultural land uses. Taskinas Creek is located on the southern side of the York River, 

agricultural land uses.

269

TABLE 1. Tidal marsh geomorphic settings (Adapted from Barnard and Doumlele 1979)

\begin{tabular}{lll}
\hline Form & Description \\
\hline Fringe marsh & $\begin{array}{l}\text { A marsh which borders along } \\
\text { a section of shoreline and } \\
\text { generally has a much greater } \\
\text { length than width. }\end{array}$ \\
\hline Embayed marsh & $\begin{array}{l}\text { V-shaped marshes that form } \\
\text { along the edges and upper } \\
\text { reaches of creeks }\end{array}$ \\
\hline
\end{tabular}

Extensive marsh

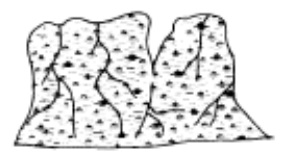
A large marsh where the length and depth or width are roughly comparable; most extensive marshes are drained by many tidal channels and creeks; attached to land on one edge

\subsection{Tidal Marsh Model (TMM)}

The TMM presents an advanced modeling framework that integrates the physical, and human components needed to simulate and assess the evolution and persistence of tidal marshes under different sea-level rise scenarios. The TMM is a finite-element model that uses a flexible unstructured grid in the simulations. Appendices A and B describe the physical and numerical formulations, respectively. The TMM is coupled to three major components in SCHISM: the hydrodynamic core that serves as the foundation of the SCHISM modeling system; the wind wave model (WWM-III); and the 3D sediment transport model (CSTMS) (Figure 2). Governing equations for WWM-III and CSTMS are displayed in Appendix C. Relative SLR is explicitly accounted for in all modules. The TMM was 
283

284

285

286

287

288

tested through hindcasting in two case study regions. The SLR rate $\left(4 \mathrm{~mm} \mathrm{yr}^{-1}\right)$ for these areas during the study period (the past 40 years) was obtained from the literature and NOAA Sea Level Trends (NOAA Tides and Currents). This rate was imposed via the boundary condition at the model's ocean boundary (the calculated elevation and velocity are shared by all components of the model). WWM-III (Roland 2009; Roland et al. 2012) is a community-driven, parallel and advanced numerical framework that can be applied to study wave-current interactions based on unstructured grids. CSTMS is an adaptation from Warner et al. (2008).

Using a process-based morphodynamic model to conduct long-term simulations requires intensive computational time. This is due to the fact that morphological changes take place over a much longer time period than hydrodynamic changes. To reduce the computational burden, a morphological acceleration factor (MAF) was used. The MAF is an approach introduced by Lesser et al. (2004) and Roelvink (2006) for coastal morphodynamic modeling, and broadly explained in Roelvink and Reniers (2011). In this approach, the speed of morphological changes is scaled up by a rate that is appropriate given the underlying hydrodynamics. This is accomplished by multiplying the bed level changes (sediment fluxes from and to the bed) by a constant factor (i.e., MAF) after each hydrodynamic time step. This allows the simultaneous computation of sediment transport and morphological change with the hydrodynamics (Moerman, 2011; Styles et al. 2016). For instance, a simulation of 1 year and a MAF of 40 would produce 40 years of sediment transport and morphological change with the computational time associated with only 1 year of simulation time. This factor is applied after all hydrodynamic and sediment transport processes have been computed for each time step. This procedure is repeated at each time step. A basic assumption is that most of the sedimentary processes are periodic in nature (but not necessarily linear, as the feedback between hydrodynamics and morphology can be nonlinear as well). Episodic and extreme events (e.g., storms, hurricanes) can be accounted for by 'turning off' the morphological acceleration during such periods. In this study, for the hindcast, the sediment transport model was run with morphological acceleration 
308 (i.e., simulation $=1$ year and MAF $=40$ ). The model was calibrated primarily by adjusting the 309 erodability constant and the time step (with a final chosen value of 75 seconds). Ancillary outputs from 310 the hydrodynamic, sediment, and wind wave modules include surface and bottom elevations, bed 311 fraction, and wave height, among others.

The TMM simulates marsh migration under the joint influence of tides, wind waves, sediment transport (including loading from upland erosion), shoreline structures, land use, and precipitation. TMM utilizes inundation frequency based on the water-surface level predicted by the modeling system to drive inundation and horizontal marsh migration. This new approach accounts for shoreline changes, marsh accretion through mineral sediment deposition, upland erosion inputs at the marsh edge (derived from the Revised Universal Soil Loss Equation - RUSLE) (Renard et al. 1991), and marsh upland transgression under a changing sea level with constraints from physical barriers (e.g., shoreline erosion control structures). Shoreline hardening structures that protect upland property from erosion (e.g., seawalls, revetments, and bulkheads) act not only as barriers for marshes to migrate inland, but also represent barriers for sediment exchange between the marsh habitat and the upland. In the model, these structures are treated as impenetrable barriers for sediment transport (but can be topped by water). We have not currently incorporated other more specific processes related to marsh stability; for example, sophisticated wave erosion formulations near the marsh edge (e.g., Beudin et al. 2017); these are left for future studies. an unstructured grid, which allows highly resolved marsh areas (1-meter cross-shore and 5-10 meters along-shore for fringe marshes) that are needed to accurately capture the migration process over a long

329 time period. At the moment, marsh elements (i.e., grid cells denoted as marsh) are represented by an 330 increased bottom roughness factor (Ye et al. 2013). Marsh areas were assigned with a roughness factor 331 of $50 \mathrm{~mm}$, while non-marsh areas were designated with a value of $1 \mathrm{~mm}$. Nevertheless, the vegetation 
332 effects (form drag and turbulence) (Zhang et al. 2019) can be incorporated into the model once more

333 detailed information on vegetation parameters is obtained; this is left for future work.

The TMM code stipulates that marshes migrate into an area if the sediment bed elevations fall

within the 'suitable' elevation range relative to mean-sea level (MSL). In this region, marshes occur

from MSL to $1 \mathrm{~m}$ above MSL. Note that MSL is changing over time due to SLR; therefore, marshes

will drown in a region if the sediment bed elevation falls below MSL. The sediment bed elevation is

dynamically calculated at each time step by the CSTMS, which simulates sediment erosion, deposition

and transport. In the code, marsh presence/absence is marked within each unstructured-grid cell.

Additional constraints are imposed for migration: a cell can become 'marsh' at the new time step only

if at least one of its adjacent cells was marsh at the previous time step; and anthropogenic structures

serve as barriers to migration (i.e., these cells can never become marsh and prevent adjacent upland

cells from becoming marsh). To that end, a spatially explicit and highly resolved inventory of shoreline

conditions (i.e., riparian land use, shoreline structures, and bank height) are used as data inputs in the

model. As mentioned before, shoreline erosion control structures placed on the landward edge of the

marsh will not only represent an impediment for marsh transgression, but also will act as barriers for

sediment exchange between the marsh and adjacent upland.

The main TMM outputs are files depicting marsh distribution at specified output time intervals.

Files are then exported to a GIS environment for further spatial analysis and visualization (e.g., interactive map viewers).

\subsection{Data Collection and Processing}

A suite of major input datasets was used by the TMM and supporting models (Table 2). 
through 1980, depending on location and locality. The process generated 1:24,000 scale maps

delineating tidal marshes. The current Tidal Marsh Inventory for the York River is based on a survey conducted in 2010. Marshes were digitized (1:1000 scale) using high resolution, geo-referenced natural color imagery collected in 2009 by the Virginia Base Mapping Program. Marsh boundaries were field checked. In addition, data from drone flights (DJI Mavic Pro Drone) were collected and analyzed for this study. The photos taken of the study area were 12-megapixel resolution and the videos were $4 \mathrm{~K}$ resolution. bottom sediments and marsh surface sediments. Tidal creek bottom cores were gathered to provide model input information on roughness and shear strength, whereas marsh surface cores were used for model verification purposes. Surficial (upper $10 \mathrm{~cm}$ ) tidal creek cores were collected along 8 transects in the primary tidal creeks. At each transect, 3 sediment cores were taken, one in the middle of the creek bed and the other ones at each creek bank, for a total of 24 samples. Surficial (upper $8 \mathrm{~cm}$ ) marsh surface sediment cores were collected along 20 transects at each study site (Figure 4); each transect consisted of 3 stations, incorporating the marsh-water interface, middle marsh, and marsh-upland interface, for a total of 60 cores.

Sediment texture was classified using the Wentworth scale into gravel: 2-4 mm, sand: 0.062-2 mm, and mud (i.e., silt and clay): $<0.062 \mathrm{~mm}$. Taskinas Creek bottom samples were predominantly mud, with less than 3-6\% of organic content and insignificant amounts of carbonates. These core samples were sieved for grain size analysis (Folk 1980, Poppe et al 2003, Haywick 2004). Taskinas Creek marsh samples and Carter Creek bottom and marsh samples were processed using sieve analysis (Folk 1980, Poppe et al. 2003). Prior to sieving, removal of organics was performed using loss on ignition, and carbonates were removed by $\mathrm{HCl}$ acidification of the dried samples (Dean 1974; Heiri et al. 2001: Santisteban et al. 2004). 
Additional field work activities were conducted to improve specific data inputs for the study

areas. Shallow water bathymetry data were collected using a Humminbird 1197 side imaging sonar

unit, an HDS 10 first generation with an HST_DFSBL Deep water transducer, and a vertically

controlled, atmospheric pressure corrected YSI 6600 V2 sonde to correct for water level changes

during bathymetric survey periods. Bathymetric data were interpolated with LIDAR data (USGS,

2011) to create a seamless topobathy surface (i.e., Digital Elevation Model, DEM) in each of the study

areas, using ESRI ArcGIS ${ }^{\circledR}$ v10.4.1. Outside the study areas (i.e., York River and Chesapeake Bay),

elevation data were extracted from the USGS Topobathymetric Digital Elevation Model for the

Chesapeake Bay (Danielson et al. 2016).

To perform the hindcast, the DEM was modified to reflect initial elevation conditions for the

marshes. Due to limited historic data to recreate the initial marsh elevations, certain topographic

adjustments were incorporated into the DEM. Different topographic correction methodologies have

been used in similar studies to estimate the elevations of the marsh platform (e.g., Clough et al. 2010;

Geselbracht et al. 2011; Glick et al. 2013; Mogensen and Rogers 2018; Alizad et al. 2018). For

example, one technique adjusted the DEM by applying the same elevations of other marsh systems that

have analogous marsh productivity and density of similar species. Another approach is a retrospective

analysis that forces the present DEM to represent a prior time period through the modification of

elevations based on the historic rate of SLR. These approaches, as well as any other alteration, create uncertainties associated with the corrected DEM.

Based on the data available for the study areas, we decided to perform topographic adjustments

using the historic tidal marsh layers (Moore and Silberhorn 1976; Moore and Silberhorn 1980) to 
406 ArcGIS were used to recode those marsh areas associated with elevations outside the suitable range.

407 Only some areas of the historic marsh polygons were associated with elevations below MSL. These 408 areas of the DEM were adjusted to $0.5 \mathrm{~m}$ (above MSL), the midpoint of the suitable elevation range for 409 marshes. The midpoint method was employed to minimize the error between the two extremes of the 410 elevation range for marsh presence. As with any other topographic adjustment, it is recognized that this 411 approach adds uncertainty to the methodology. Nevertheless, the midpoint method provided a more 412 realistic initial condition using the available data. This adjustment assured that the spatial extent of all 413 historic marshes had elevations within the suitable tidal range to start the hindcast. Other elevations 414 within the domain were not modified to avoid introducing extra uncertainty in the simulations.

415

TABLE 2. Primary input datasets used for TMM and supporting models

\begin{tabular}{|c|c|}
\hline Dataset & Source \\
\hline Historic Tidal Marshes $(1: 24,000)$ & Tidal Marsh Inventories - CCRM, VIMS \\
\hline \multicolumn{2}{|l|}{ Current Tidal Marshes (Scale: 1:1,000) } \\
\hline Shoreline Structures & Shoreline Inventory Program - CCRM, VIMS \\
\hline Riparian Land use (distance & Shoreline Inventory Program - CCRM, VIMS \\
\hline LIDAR data & United States Geological Survey (USGS) \\
\hline Bathymetry & NOAA and CBNERR, VIMS \\
\hline Bottom Type (grain sizes) & VIMS, Maryland Geological Survey (MGS), and field samples \\
\hline River Input (average daily values) & United States Geological Survey (USGS) \\
\hline Total Suspended Solids & Chesapeake Bay Program \\
\hline Atmospheric Forcing & North American Regional Reanalysis (NARR) \\
\hline Tides & US East Coast Tidal Database \\
\hline
\end{tabular}

417 


\subsection{Grid Generation}

The grids used in this study were generated using the Surface-water Modeling System (SMS)

developed by Aquaveo, LLC (aquaveo.com). SMS is a graphical interface used to create, visualize,

objects in SMS to define all relevant features within the domain (i.e., adjacent riparian upland,

marshes, shoreline structures, channels, as well as other important physical features affecting water

circulation). Marsh areas are highly resolved (i.e., fringe marshes are 1-m cross-shore and 5-10 m

$20 \mathrm{~m}$ resolution in the interior of the marsh). A finer grid resolution was applied in uplands adjacent to

marshes to accurately capture marsh transgression from SLR; beyond these areas, a transition to

coarser resolution was used to account for rare inundation. Figures 5 and 6 show the grid generated for

Carter Creek and Taskinas Creek respectively. These figures show the high resolution that is used

within marsh systems as well as the adjacent upland areas to assess marsh transgression. Extremely

rapid transitions in grid resolution are used to save computational cost (the grid size would be more allows very skewed elements (i.e., grid cells) to be used, with skewness being defined as the ratio of the largest side of a triangle and its equivalent diameter (diameter of a circle having the same area as the triangle). For reference, an equilateral triangle has a skewness of 1.35. The TMM supports very skew elements (skewness exceeding 20), which are common around high resolution areas. This advantage when compared with other model approaches. without any further smoothing as is commonly done by other models (Ye et al. 2018). A seamless 
uniform $1 \mathrm{~m}$ resolution for the Chesapeake Bay. Inside Carter Creek and Taskinas Creek, bathymetry

444 data were updated with field measurements to achieve more accurate shallow water depths. In this case,

445

446

447

448

449

450

451

452

453

454

455

456

457

new interpolations were conducted using the LIDAR data and the updated bathymetry to generate a

seamless topo-bathy surface. TMM is an elevation driven model, so accurate elevations are critical for the reliability of the model outputs.

\section{Results and Evaluation of Model Performance}

The main purpose of this evaluation was to demonstrate that model formulation and

performance were sufficiently accurate for the purpose of the study. It is recognized that there are

degrees of uncertainty associated with both modeling and field observation methodologies.

A critical step in this process was to verify that assumptions and principles were accurately

represented in the mathematical equations and computer code. Different components of the modeling

system have been rigorously benchmarked by many groups (Roland 2012; Pinto 2012; Zhang et al.

2019), and the base code is also regularly subjected to regression tests via Apache Subversion (SVN)

as part of our software engineering process. SVN is a software versioning and control tool.

We assessed model outputs against field observations focusing on two main aspects: (1) marsh

boundary evolution and (2) distribution of marsh sediments. The evaluation of these two features

allowed us to determine the degree of agreement between model prediction and observations. Various

statistics and metrics were calculated to describe model performance; descriptions are provided below.

\subsection{Marsh Boundary Evolution}

Outputs from the TMM were exported to the GIS environment using Matlab and Fortran scripts. Spatial analyses were conducted using ESRI ArcGIS ${ }^{\circledR}$ v10.4.1.

Historic and field data were used for calibration and verification purposes. Model performance was evaluated by conducting a hindcast using the historic VIMS Tidal Marsh Inventory as the initial 
marsh conditions for the model simulations. The modified DEM based on the historic tidal marsh layers (Moore and Silberhorn 1976; Moore and Silberhorn 1980) was used for the initial elevation conditions. The TMM was run to the present time (simulation: past 40 years), and the model outputs were then compared with the current Tidal Marsh Inventory developed by CCRM, VIMS. Figures 7 and 8 display the spatial marsh distribution pattern generated by the model. These outputs are products not only of the model formulations, but also reflect the accuracy of the model inputs (i.e., initial conditions). For example, in the case of Taskinas Creek, the marsh loss observed in the upper tributary corresponds to an initial condition (i.e., historic tidal marsh inventory), indicating marsh presence in that particular area. Over the 40-year simulation, that section of the marsh was fragmented, creating a channel; the model outputs correspond with the current observations of marsh extent in that zone. Model outputs of marsh boundaries reflect the results of the physical processes expected in these systems. For example, outside the mouth of Taskinas Creek on the main stem of the York River, we observe substantial marsh loss at the leading edge, most likely due to the high fetch and wave energy. In addition, within the inner creek, the model captures sediment deposition on the inner bank of the meander (convex side), and erosion on the outer bank of the creek (concave side), which is typical of meandering creek dynamics. This pattern is also observed in the upper region of Carter

Creek, where the creek adopts a sinusoidal form. Since marshes in Carter Creek are associated with different land uses, we observe different patterns in marsh transgression. Marsh boundary outputs show how the model captures marsh transgression in open areas (this pattern is seen in Taskinas Creek as well), and how this inland marsh migration is truncated by the presence of structures or development, such as in the case of roads located at the marsh-upland edge.

Error matrices were created to statistically quantify the degree to which the model reproduced the observed data. These allowed the assessment of the overall accuracy of the model and to calculate the Kappa statistic, a measure of agreement between the model output and the reference data (i.e., the current Tidal Marsh Inventory). Kappa is a robust statistic and is the most commonly reported measure 
493 in assessing model agreement using categorical variables with multiple levels (McHugh 2012; Tang et al. 2015).

In each study area, an error matrix was developed by using 100 random sample points (Figure

9), which were employed to determine if the current marsh conditions at those locations agree with the

conditions predicted by the model. Tables 3 and 4 display the results of the matrices. Table 5 shows a commonly cited scale to interpret the value of the Kappa statistic (Landis and Koch 1977; Viera et al.

2005). In Carter Creek, the model performed with an overall accuracy of $81 \%$ and with a Kappa

Creek, the model is performing with an overall accuracy of $78 \%$ and with a Kappa statistic of 0.613 ,

TABLE 3. Error Matrix for Carter Creek based on 100 random sample points. Each point was used to evaluate if the current marsh conditions at that location agree with the conditions predicted by the

\begin{tabular}{|c|c|c|c|c|c|c|}
\hline $\begin{array}{c}\text { CARTER } \\
\text { CREEK }\end{array}$ & \multicolumn{5}{|c|}{ Current Tidal Marsh Inventory } \\
\hline & No Change & Marsh Gain & Marsh Loss & TOTAL & $\begin{array}{c}\text { Commission } \\
\text { Error }\end{array}$ \\
\cline { 2 - 7 } & No Change & 45 & 2 & 7 & 54 & 0.17 \\
\cline { 2 - 7 } & Marsh Gain & 2 & 8 & 0 & 10 & 0.20 \\
\cline { 2 - 7 } $\begin{array}{c}\text { Tidal Marsh } \\
\text { Model } \\
\text { (TMM) }\end{array}$ & Marsh Loss & 8 & 0 & 28 & 36 & 0.22 \\
\cline { 2 - 7 } & TOTAL & 55 & 10 & 35 & 100 & \\
\cline { 2 - 7 } & $\begin{array}{c}\text { Omission } \\
\text { Error }\end{array}$ & 0.18 & 0.20 & 0.20 & & 0.19 \\
\hline
\end{tabular}

Commission and omission errors defined as: 


\begin{tabular}{|c|c|c|c|c|c|c|c|c|}
\hline \multicolumn{9}{|c|}{ Levels of Agreement } \\
\hline & $\begin{array}{c}\text { Less than chance } \\
\text { agreement }\end{array}$ & $\begin{array}{c}\text { Slight } \\
\text { agreement }\end{array}$ & \multicolumn{2}{|c|}{$\begin{array}{c}\text { Fair } \\
\text { agreement }\end{array}$} & $\begin{array}{l}\text { Moderate } \\
\text { agreement }\end{array}$ & \multicolumn{2}{|c|}{$\begin{array}{c}\text { Substantial } \\
\text { agreement }\end{array}$} & $\begin{array}{l}\text { Almost perfect } \\
\text { agreement }\end{array}$ \\
\hline $\begin{array}{c}\text { Kappa } \\
\text { Statistic }^{\text {a }}\end{array}$ & $<0$ & $0.01-0.20$ & \multicolumn{2}{|c|}{$0.21-0.40$} & $0.41-0.60$ & \multicolumn{2}{|c|}{$0.61-0.80$} & 0.81-0.99 \\
\hline \multicolumn{9}{|c|}{ Levels of Agreement } \\
\hline & Unsatisfactory & \multicolumn{2}{|c|}{ Satisfactory } & \multicolumn{3}{|c|}{ Good } & \multicolumn{2}{|r|}{ Very Good } \\
\hline $\mathrm{NSE}^{\mathrm{b}}$ & $<0.50$ & \multicolumn{2}{|c|}{$0.50<\mathrm{NSE}<0.65$} & \multicolumn{3}{|c|}{$0.65<\mathrm{NSE}<0.75$} & \multicolumn{2}{|c|}{$0.75<\mathrm{NSE}<1.0$} \\
\hline $\mathrm{RSR}^{\mathrm{c}}$ & $>0.70$ & \multicolumn{2}{|c|}{$0.60<\mathrm{RSR}<0.70$} & \multicolumn{3}{|c|}{$0.50<\mathrm{RSR}<0.60$} & \multicolumn{2}{|c|}{$0.00<\mathrm{RSR}<0.50$} \\
\hline \multicolumn{9}{|c|}{ Levels of Agreement } \\
\hline & & \multicolumn{2}{|c|}{ Possible values } & \multicolumn{3}{|c|}{ Optimal value } & \multicolumn{2}{|c|}{ Preferred values } \\
\hline & $\mathrm{MAE}^{\mathrm{d}}$ & & & & 0 & & & Low values \\
\hline \multirow{2}{*}{\multicolumn{2}{|c|}{ Willmott index of agreement ${ }^{\mathrm{e}}$}} & \multirow{2}{*}{\multicolumn{2}{|c|}{0 to 1}} & \multirow{2}{*}{\multicolumn{3}{|c|}{1}} & & 0.5 to $1.0^{\mathrm{f}}$ \\
\hline & & & & & & & & $>0.8^{g}$ \\
\hline
\end{tabular}

521

TABLE 4. Error Matrix for Taskinas Creek based on 100 random sample points. Each point was used to evaluate if the current marsh conditions at that location agree with the conditions predicted by the model. Gray diagonal represents the counts where model outputs and current conditions agree

\begin{tabular}{|c|c|c|c|c|c|c|}
\hline \multirow{2}{*}{$\begin{array}{c}\text { TASKINAS } \\
\text { CREEK }\end{array}$} & \multicolumn{7}{|c|}{ Current Tidal Marsh Inventory } \\
\hline & No Change & Marsh Gain & Marsh Loss & TOTAL & $\begin{array}{c}\text { Commission } \\
\text { Error }\end{array}$ \\
\cline { 2 - 7 } & No Change & 48 & 5 & 6 & 59 & 0.19 \\
\cline { 2 - 7 } & Marsh Gain & 3 & 16 & 0 & 19 & 0.16 \\
\cline { 2 - 7 } $\begin{array}{c}\text { Tidal Marsh } \\
\text { Model } \\
\text { (TMM) }\end{array}$ & Marsh Loss & 8 & 0 & 14 & 22 & 0.36 \\
\cline { 2 - 7 } & TOTAL & 59 & 21 & 20 & 100 & \\
\cline { 2 - 7 } & $\begin{array}{c}\text { Omission } \\
\text { Error }\end{array}$ & 0.19 & 0.24 & 0.30 & & 0.22 \\
\hline
\end{tabular}

TABLE 5. Interpretation of the model performance measures

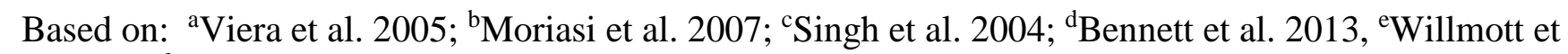
al. 2012; ' Machiwal and Jha, 2015; ' De Jager, 1994. 


\subsection{Spatial Distribution of Sediments - Grain size}

Regarding the spatial distribution of sediment texture across the marshes, surface sediments in

526 Carter Creek are characterized mainly by coarse sediments (e.g., sand) distributed throughout the

527 creekbank, in the middle of the marsh, and by the marsh-upland interface. This may be a reflection of

528 Carter Creek being located in a higher energy setting (as compared to Taskinas Creek, which is a more

529 protected embayed marsh). Carter Creek has fringing 'type' marshes that allow for greater interaction

530 between the entire marsh system with storm and upland deposition events. In Taskinas Creek, coarser

531 textured sediments tend to be located at the marsh-water edge, with fine sediment (i.e., mud)

532 characteristics of marsh interior sites. Exceptions occur at some upland edges that receive upland 533 erosion deposits.

Different statistical descriptors were used to evaluate the model's ability to reproduce the

distribution of observed marsh sediment fractions (i.e., sediment texture). For this study, model

outputs and field observations were compared using the most commonly employed model assessment

or model efficiency statistics (e.g. Legates and McCabe Jr., 1999; Bennet et al. 2013; Moriasi et al.

2007; Willmott et al. 2015; Meskini-Vishkaee and Davatgar, 2018): the mean absolute error of

measured values (MAE); Willmott (1982) index of agreement (dr); the coefficient of determination

(NSE), and the RMSE-standard deviation ratio (RSR). Appendix D displays the equations for these

statistical performance measures. Table 5 shows the range of values of these statistics and the

interpretation of the model performance. Values obtained for both study areas are presented in Table 6.

Results for Carter Creek show a strong agreement between model outputs and observations

(Table 6). All statistics support the model predictions of the surface sediment distribution along the

marshes. These results suggest that the TMM captures very well the physical processes related to 
549 RSR statistics fall within the satisfactory agreement category (based on Moriasi et al. 2007; Singh et al.

550 2004). These two statistics display a lower agreement between the model prediction and observations

551 when compared with the results of Carter Creek area. This difference can be attributed to disagreement

552 between model outputs and field observations in three marsh sections sampled in Taskinas Creek.

553 Field samples were verified and sites were examined again through field visits and drone flights. The

554 Taskinas Creek system has areas with localized anomalies (e.g. Figures 10 a, b, and c), such as terrain

555 depressions, very narrow marsh channels, high slope upland-marsh banks, and upland-marsh interface

556 vegetation with different tree canopies, which affects plant marsh growth and soil conditions. In some

557 cases, these differences could also be attributed to temporal variations in TSS loadings not captured by

558 the model.

559

560

561

562

TABLE 6. Marsh sediment fraction distribution: comparison between model outputs and field observations (from grain size analysis)

\begin{tabular}{|c|c|c|c|c|c|}
\hline & & $\begin{array}{c}\text { Mean } \\
\text { Absolute } \\
\text { Error } \\
\text { (MAE) }\end{array}$ & $\begin{array}{c}\text { Observations } \\
\text { Standard } \\
\text { Deviation } \\
\text { Ratio (RSR) }\end{array}$ & $\begin{array}{c}\text { Nash_Sutcliffe } \\
\text { Efficiency } \\
\text { (NSE) }\end{array}$ & $\begin{array}{l}\text { Willmott } \\
\text { Modified } \\
\text { Index of } \\
\text { Agreement } \\
\text { (dr) }\end{array}$ \\
\hline \multirow{2}{*}{$\begin{array}{c}\text { Carter } \\
\text { Creek }\end{array}$} & Sand & 0.08 & 0.43 & 0.81 & 0.86 \\
\hline & Mud & 0.08 & 0.43 & 0.81 & 0.86 \\
\hline \multirow{2}{*}{$\begin{array}{c}\text { Taskinas } \\
\text { Creek }\end{array}$} & Sand & 0.10 & 0.61 & 0.62 & 0.83 \\
\hline & Mud & 0.10 & 0.61 & 0.62 & 0.83 \\
\hline
\end{tabular}

563

564

565

566

567 
We have developed a new approach to simulate marsh evolution. This innovative model, tested

571 for accuracy via hindcasting, will advance the state of the science by building a better foundation to model marsh extent and distribution. Major features included in the TMM are cross-scale simulations

573 through the use of unstructured grids; semi-implicit time stepping; dynamic rates incorporated in the

574 simulations (i.e., rates vary in space and time as determined by changes in the hydrodynamic

575 conditions of the system); and highly resolved marsh transgression. The TMM has been successfully

576 applied in two marsh creek systems in the York River estuary (USA). The sites present different

577 physical settings (i.e., wave regime, sediment supply, topography), and distinctive anthropogenic

578 stressors (i.e., riparian land use, shoreline hardened structures). In addition, both creeks are dominated

579 by different marsh geomorphic settings (i.e., embayed, and fringe marshes). The TMM has been

580 developed to be exportable to other geomorphic systems, including estuaries, back-barrier islands,

581 fluvially-dominated deltas, and lagoons. Application of this model to other regions will be limited

582 mainly by the available input data for the target areas.

The initial version of this dynamic high-resolution model incorporates key physical processes

584 that directly influence marsh persistence, such as erosion, inundation, sediment transport, and surface

585 elevation change, all of which directly affect marsh vertical accretion and horizontal migration.

586 Based on accelerated projections of SLR, it is expected that marshes will rely considerably on

587 inorganic sediment supplies to offset changes in water level. Once primary production and organic 588 deposition of marsh plants reach maximum rates, the fate of marshes will depend on their capacity to 589 capture and retain inorganic sediment, as well as the ability to migrate inland if there are adjacent open 590 spaces that allow transgression. For that reason, understanding and successfully simulating physical 591 factors and processes are critical initial steps to forecast the fate of tidal marshes. 

representation of the horizontal sediment distribution along marshes in Carter Creek. For Taskinas

594 Creek, the horizontal distribution of sediments was satisfactorily captured by the model. Major differences between model outputs and field observations in Taskinas Creek can be attributed to the heterogeneity of the system at sub-grid scales. Ultimately, there is a trade-off between increasing resolution and complexity, and exportability of the model. Efforts to maximize details as well as to increase the degree of freedom generally lead to excessive parameterization, larger model uncertainty, and error propagation (Anderson 2005; Hood et al. 2006). For that reason, it is imperative to clearly define the purpose of the model and the type of research and management questions that model simulations are to address. In addition, it is fundamental to have the necessary data to support parameterization. In the case of a heterogeneous system (i.e., with multiple geomorphic settings), end users need to evaluate the overall purpose and application of the model, as well as the amount of error that they are willing to accept.

We have demonstrated that the TMM is able to successfully simulate the physical processes related to marsh persistence and evolution. Simulations of marsh boundary evolution (i.e., marsh landward migration and marsh erosion) produced a substantial agreement with the current marsh conditions in both study areas. Marsh migration into open areas was well captured, as well as the negative effect of hardened shoreline structures and development on the natural capacity of marshes to migrate inland as sea-level rises. narrow fringing marshes. These types of marshes provide many ecosystem services that extensive marshes offer (Bilkovic et al. 2016). Different studies show that more than $60 \%$ of the wave attenuation by marshes occurs within the first meters of the marsh (Knutson et al. 1982; Morgan et al. 
617 sediment and nutrient removal by marshes occurs along the marsh edge and upland border (Tobias et 618 al. 2001; Neubauer et al. 2002; Burke et al. 2005). These findings suggest that narrow fringe marshes 619 also play a critical role in water quality. For that reason, it is essential to capture these narrow habitats 620 when modeling marsh evolution in order to more accurately assess overall marsh stability and sustainability of the system.

The model's capacity to predict future marsh extent and distribution based on the simulation of physical processes and anthropogenic factors has diverse implications for coastal managers. Under higher sea-level-rise scenarios, many marshes will likely cross thresholds and experience significant and irreversible changes, such as marsh fragmentation and total disintegration due to erosion or drowning. It is imperative to develop monitoring strategies and simulation models to determine if an ecosystem is approaching a threshold. This can increase knowledge of the system dynamics. The highly resolved TMM outputs will allow coastal planners and managers to more precisely identify, prioritize, and develop protection and restoration activities and strategies to preserve these essential ecosystems, and to test potential impacts of human modification to coastal systems. over a 40-year period of observation based on physical processes and factors. At this stage of model development, biological processes have not been incorporated in the simulations, which may limit the model's applicability to other areas where the vertical accretion of marshes is currently dominated by organic matter production and/or deposition. A biological model is currently being developed to contribute to the physical model. Nevertheless, this unique approach of simulating marsh evolution based only on physical processes and factors will provide coastal managers with a more accurate tool to initially determine the fate of tidal marshes over large areas, especially in those cases where biological parameters are extremely variable and detailed data are too limited to properly simulate the biological response of marshes as sea level rises. 
642 address many rather complex processes. The coupling of TMM to SCHISM requires predictive values

643 from different tools, and yet the corresponding governing evolution equations used by these tools and

644 those described in Appendix C may be too simplistic to capture the real-world physics. For example, as

645 mentioned above, more sophisticated formulations for wave erosion at marsh edges may improve the

646 localized processes for marsh stability there. A 3D model that includes salinity and temperature

647 together with a new biological module can further improve the model's predictive capability for the

648 fate of certain marsh species under climate change. Although some sensitivity to mesh resolution has

649 been carried out, more analysis on this in the larger context of other uncertainties should be explored

650 further. Lastly, more site-specific input information is being collected that may be able to further

651 validate and improve the model.

652

653

654

655

A multi-scale model to simulate marsh evolution has been presented. This novel model,

developed as a module within the SCHISM framework, has been shown to be suitable to efficiently

interpolate site-specific information across critical conditions creating the capacity to assess marsh

658

vulnerability under present and potential future condition. The TMM will advance the state of the

science by building a better foundation to simulate marsh extent and distribution, allowing coastal

planners to more accurately manage these valuable habitats and their ecological services.

661

662

663

664

665 


\section{List of Figures:}

Fig. 1 Diagram of vertical and horizontal marsh responses to sea-level rise Symbols courtesy of the Integration and Application Network (ian.umces.edu/symbols/), University of Maryland Center for Environmental Science

Fig. 2 SCHISM modeling system. The dashed box indicates the TMM and key supporting components. The hydrostatic core serves as the pillar of the system to provide hydrodynamic variables to other models as well as to facilitate exchange of variables between models in a parallel software environment

Fig. 3 a) York River system; b) Carter Creek and c) Taskinas Creek: study areas in the York River. Bright green areas represent tidal marshes. Background Image: VBMP2017/VBMP2017_ WGS Virginia Geographic Information Network (VGIN)

Fig. 4 Locations of marsh near surface (upper eight $\mathrm{cm}$ ) sediment cores sampled in a) Carter Creek (33 cores) and b) Taskinas Creek (27 cores). Background Image: VBMP2017/VBMP2017_WGS Virginia Geographic Information Network (VGIN)

Fig. 5 a) Unstructured TMM grid used for Carter Creek marshes; b) The marsh layer (in green) is displayed on top of the grid (in yellow). Upland adjacent to the marsh is highly resolved to more accurately capture marsh transgression. Background Image: VBMP2017/VBMP2017_ WGS - Virginia Geographic Information Network (VGIN)

Fig. 6 a) Unstructured TMM grid used for Taskinas Creek marshes; b) The marsh layer (in green) is displayed on top of the grid (in yellow). Upland adjacent to the marsh is highly resolved to more accurately capture marsh transgression. Background Image: VBMP2017/VBMP2017_WGS - Virginia Geographic Information Network (VGIN)

Fig. 7 Marsh boundary evolution output for Carter Creek - Hindcast outputs: changes in marsh boundary after 40 years of simulation with a sea-level rise of $4 \mathrm{~mm} / \mathrm{yr}$. Background image: VBMP2017/VBMP2017_WGS - Virginia Geographic Information Network (VGIN)

Fig. 8 Marsh boundary evolution output for Taskinas Creek - Hindcast outputs: changes in marsh boundary after 40 years of simulation with a sea-level rise of $4 \mathrm{~mm} / \mathrm{yr}$. Background image: VBMP2017/VBMP2017_WGS - Virginia Geographic Information Network (VGIN)

Fig. 9 Points used to generate the error matrices in a) Carter Creek (100 points) and Taskinas Creek (100 points). Points were generated using ArcGIS point generator. Background image: VBMP2017/VBMP2017_Infrared_WGS - Virginia Geographic Information Network (VGIN)

Fig. 10 Aerial drone photos of Taskinas Creek - a) it displays different soil conditions around marsh channels; b) localized depressions can be seen close to the upland edge (red box); c) it shows marsh areas affected by the presence of tree canopies

Fig. 11 Basic 3D computational unit (triangular element) in SCHISM. The elevation ( $\eta$ ) is defined at node (vertex) of a triangular element, horizontal velocity $(u, v)$ at side center and whole levels, vertical velocity $(w)$ at element centroid and whole level, and tracers $(C)$ at the prism center 


\section{References}

Alizad K., Hagen SC, Morris JT, Bacopoulos P, Bilskie MV, Weishampel JF, Medeiros SC (2016) A coupled, two-dimensional hydrodynamic-marsh model with biological feedback. Ecol. Modell 327:2943. https://doi.org/10.1016/j.ecolmodel.2016.01.013

Anderson T (2005) Plankton functional type modeling: Running before we can walk? Journal of Plankton Research 27(11):1073-1081. https://doi.org/10.1093/plankt/fbm024

Azevedo A, Oliveira A, Fortunato AB, Zhang Y, Baptista AM (2014) A cross-scale numerical modeling system for management support of oil spill accidents. Marine Pollution Bulletin 80:132-147.

Barnard T, Doumlele DG, Silberhorn GM (1979) City of Virginia Beach Marsh Inventory: Volume 2 Lynnhaven River, Lake Rudee and Their Tributaries. Virginia Institute of Marine Science. SRAMSOE 217. https://doi.org/10.21220/V5MH85

Bennett N, Croke BFW, Guariso G, Guillaume JHA, Hamilton SH, Jakeman AJ, Marsili-Libelli S, Newham LTH, Norton JP, Perrin C, Pierce SA, Robson B, Seppelt R, Voinov AA, Fath BD, Andreassian V (2013) Characterising performance of environmental models. Environmental Modelling \& Software 40:1-20. https://doi.org/10.1016/j.envsoft.2012.09.011

Beudin A, Kalra TS, Ganju NK, Warner JC (2017) Development of a coupled wave-flow-vegetation interaction model. Computers \& Geosciences 100:76-86. https://doi.org/10.1016/j.cageo.2016.12.010

Bilkovic DM, Mitchell M, Mason P, Duhring K (2016) The role of living shorelines as estuarine habitat conservation strategies. Coastal Management Journal 44:161-174.

http://dx.doi.org/10.1080/08920753.2016.1160201

Boon JD, Mitchell M (2015) Nonlinear Change in Sea Level Observed at North American Tide Stations. Journal of Coastal Research 31(6):1295-1305. https://doi.org/10.2112/JCOASTRES-D-1500041.1

Burke D, Koch EW, Stevenson JC (2005) Assessment of Hybrid Type Shore Erosion Control Projects in Maryland's Chesapeake Bay_Phases I \& II. Final Report for Chesapeake Bay Trust. Annapolis, MD.

Burla M, Baptista AM, Zhang Y, Frolov S. (2010) Seasonal and interannual variability of the Columbia River plume: A perspective enabled by multiyear simulation databases. Journal of Geophysical Research, 115, C00B16.

Cahoon DR, Guntenspergen GR (2010) Climate change, sea-level rise, and coastal wetlands. National Wetlands Newsletter 32:8-12.

CCRM (Center for Coastal Resources Management) (2016) Shoreline \& Tidal Marsh Inventory. College of William and Mary. Virginia Institute of Marine Science, Gloucester Point, Virginia. http://www.vims.edu/ccrm/research/inventory/index.php. Accessed 9 January 2017.

Chao Y, Farrara JD, Bjorkstedt E, Chai F, Chavez F, Rudnick D, Enright W, Fisher JL, Peterson WT, Welch GF, Davis CO, Dugdale RC, Wilkerson F., Zhang HC, Zhang YL, Ateljevich E (2017) The 
origins of the anomalous warming in the California coastal ocean and San Francisco Bay during 20142016. Journal of Geophysical Research-Oceans 122:7537-7557. https://doi.org/10.1002/2017JC013120

Clough J, Polaczyk A, Popato M (2016) Modeling the potential effects of sea-level rise on the coast of New York: Integrating mechanistic accretion and stochastic uncertainty. Environmental Modelling \& Software 84: 349-362.

Clough JS, Park RA, Fuller R (2010) SLAMM 6 beta technical documentation. Warren Pinnacle. http://warrenpinnacle.com/prof/SLAMM6/SLAMM6_Technical_Documentation.pdf. Accessed 19 September 2018.

D’Alpaos A, Lanzoni S, Marani M, Rinaldo A (2007a) Landscape evolution in tidal embayments: Modeling the interplay of erosion sedimentation and vegetation dynamics. J. Geophys. Res. 112 F01008. https://doi.org/10.1029/2006JF000537

Danielson J, Tyler D (2016) Topobathymetric Model for Chesapeake Bay Region - District of Columbia, States of Delaware, Maryland, Pennsylvania, and Virginia, 1859 to 2015. https://topotools.cr.usgs.gov/coned/chesapeake_bay.php. Accessed 2 October 2018.

Dean WE Jr (1974) Determination of carbonate and organic matter in calcareous sediments and sedimentary rocks by loss on ignition: Comparison with other methods. Journal of Sedimentary Petrology 44:242-248.

Deaton CD, Hein CJ, Kirwan ML (2017) Barrier-island migration dominates ecogeomorphic feedbacks and drives salt marsh loss along the Virginia Atlantic Coast, USA. Geology 45:123-126

De Jager JM (1994) Accuracy of vegetation evaporation ratio formulae for estimating final wheat yield. Water SA 20(4):307-314.

Du J, Shen J, Zhang YJ, Ye F, Liu Z, Wang Z, Wang YP, Yu X, Sisson M, Wang HV (2018) Tidal response to sea-level rise in different types of estuaries: The importance of length, bathymetry, and geometry. Geophysical Research Letters 45:227-235. https://doi.org/10.1002/2017GL075963

Eggleston J, Pope J (2013) Land subsidence and relative sea level rise in the southern Chesapeake Bay region. US Geological Survey Circular 1392. https://dx.doi.org/10.3133/cir1392

Enwright N, Griffith K, Osland MJ (2016) Barriers to and opportunities for landward migration of coastal wetlands with sea-level rise. Frontiers in Ecology and the Environment 14:307-316. https://doi.org/10.1002/fee.1282

Ezer T, Atkinson LP, Corlett WB, Blanco JL (2013) Gulf Stream's induced sea level rise and variability along the U.S. mid-Atlantic coast. Journal of Geophysical Research: Oceans 118:685-697. https://doi.org/10.1002/jgrc.20091

Fisher J, Acreman MC (2004) Wetland nutrient removal: a review of the evidence. Hydrology and Earth System Sciences 8:673-685. https://doi.org/10.5194/hess-8-673-2004 
Finkelstein K, Ferland MA (1987) Back-barreir response to sea-level rise, eastern shore of Virginia. In: Nummedal D, Pilkey OH, Howard JD (eds) Sea-level fluctuation and coastal evolution. SEPM, SP 41, pp 145-156.

Fitzgerald DM, Howes N, Kulp M, Hughes Z, Georgiou I, Penland S (2007) Impacts of rising sea level to backbarrier wetlands, tidal inlets, and barriers: Barataria Coast, Louisiana. Proceedings of Coastal Sediments 2007 CD-ROM13.

Folk RL (1980) Petrology of sedimentary rocks. Hemphill Publishing Company, Austin, TX.

Geselbracht L, Freeman K, Kelly E, Gordon DR, Putz FE (2011) Retrospective and prospective model simulations of sea level rise impacts on Gulf of Mexico coastal marshes and forests in Waccasassa Bay, Florida. Climatic Change 107:35-57. https://doi. org/10.1007/s10584-011-0084-y

Gittman RK, Fodrie J, Popowich AM, Keller DA, Bruno JF, Currin CA, Peterson CH, Piehler MF (2015) Engineering away our natural defenses: An analysis of shoreline hardening in the US. Frontiers in Ecology and the Environment 13(6):301 307. https://dx.doi.org/10.1093\%2Fbiosci\%2Fbiw091

Glick P, Clough J, Nunley B (2008) Sea-Level Rise and Coastal Habitats in the Chesapeake Bay Region. Technical Report. National Wildlife Federation.

Glick P, Clough J, Polaczyk A, Couvillion B, Nunley B (2013) Potential effects of sea-level rise on coastal wetlands in southeastern Louisiana. Journal of Coastal Research 63 (10063): 211-233. https://doi.org/10.2112/SI63-0017.1

Guerin T, Bertin X, Coulombier T, de Bakker A (2018) Impacts of wave-induced circulation in the surf zone on wave setup. Ocean Modelling 123:86-97. https://doi.org/10.1016/j.ocemod.2018.01.006

Hansen J, Sato M, Hearty P, Ruedy R, Kelley M, Masson-Delmotte V, Russell G, Tselioudis G, Cao J, Rignot E, Velicogna I, Kandiano E, von Schuckmann K, Kharecha P, Legrande AN, Bauer M, Lo K$\mathrm{W}$ (2016) Ice melt, sea level rise and superstorms: evidence from paleoclimate data, climate modeling, and modern observations that $2{ }^{\circ} \mathrm{C}$ global warming could be dangerous. Atmospheric Chemistry and Physics 16:3761-3812. https://doi.org/10.5194/acp-16-3761-2016

Haywick DW (2004) Pipette and Sieve Grain Size Analysis: Procedures Guide. Department of Earth Sciences. University of South Alabama.

Heiri, O, Lotter AF, Lemcke G (2001) Loss on ignition as a method for estimating organic and carbonate content in sediments: reproducibility and comparability of results. Journal of Paleolimnology 25:101-110.

Hill K (2015) Coastal infrastructure: a typology for the next century of adaptation to sea-level rise. Frontiers in Ecology and the Environment 13 (9):468-476. https://doi.org/10.2112/07A-0010.1

Hood R, Laws EA, Armstrong RA, Bates NR, Brown CW, Carlson CA, Chai F, Doney SC, Falkowski PG, Feely RA, Friedrichs MA, Landry MR, Moore JK, Nelson DM, Richardson TL, Salihoglu B, Schartau M, Toole DA, Wiggertk JD (2006) Pelagic functional group modeling: progress, challenges and prospects. Deep Sea Research Part II: Topical Studies in Oceanography 53(5):459-512. https://doi.org/10.1016/j.dsr2.2006.01.025 
Horton B, Shennan I, Bradley SL, Cahill N, Kirwan M, Kopp RE, Shaw TA (2018) Predicting marsh vulnerability to sea-level rise using Holocene relative sea-level data. Nature Communications 9(1):2697-2690. https://doi.org/10.1038/s41467-018-05080-0

Jørgensen SE, Fath BD (2011a) 10-Structurally dynamic models. In: Sven Erik J, Brian DF (Eds.), Developments in Environmental Modelling, vol. 23. Elsevier, Amsterdam, pp. 309-346.

Kirwan M, Walters DC, Reay WG, Carr JA (2016) Sea level driven marsh expansion in a coupled model of marsh erosion and migration. Geophys. Res. Lett. 43: 4366-4373, https://doi.org/10.1002/ 2016GL068507

Kirwan ML, Megonigal JP (2013) Tidal wetland stability in the face of human impacts and sea-level rise. Nature 504:53-60. https://doi.org/10.1038/nature12856

Kirwan ML, Murray AB (2007) A Coupled Geomorphic and Ecological Model of Tidal Marsh Evolution. Proceedings of the National Academy of Sciences 104 (15):6118-6122.

https://doi.org/10.1073/pnas.0700958104

Kolker AS, Kirwan ML, Goodbred SL, Cochran J K (2010) Global climate changes recorded in coastal wetland sediments: empirical observation linked to theoretical predictions. Geophys. Res. Lett. 37, L14706.

Knutson PL, Brochu RA, Seeling WN, Inskeep M (1982) Wave dampening in Spartina alterniflora marshes. Wetlands 2:87-104.

Landis JR, Koch GG (1977) The measurement of observer agreement for categorical data. Biometrics 33:159-74. https://doi.org/10.2307/2529310

Legates DR, McCabe Jr GJ (1999) Evaluating the use of "goodness-of-fit" measures in hydrologic and hydroclimatic model validation. Water Resources Research 35(1):233-241.

https://doi.org/10.1029/1998WR900018

Le Roux DY (2012) Spurious inertial oscillations in shallow-water models. Journal of Computational Physics 231:7959-7987. https://doi.org/10.1016/j.jcp.2012.04.052

Lesser GR, Roelvink JA, Van Kester J, Stelling GS (2004) Development and validation of a threedimensional morphological model. Coastal Engineering, 51(8-9):883-915.

Lin J, Kuo AY (2001) Secondary Turbidity Maximum in a Partially Mixed Microtidal Estuary. Estuaries 24:707-720. https://doi.org/10.2307/1352879

Liu Q, Anderson E, Zhang YJ, Weinke AD, Knapp KL, Biddanda BA (2018) Modeling Reveals the Role of Coastal Upwelling and Hydrologic Inputs on Biologically Distinct Water Exchanges in a Great Lakes Estuary. Estuarine, Coastal and Shelf Science 29:41-55.

https://doi.org/10.1016/j.ecss.2018.05.014 
Machiwal D, Jha MK (2015) GIS-based water balance modeling for estimating regional specific yield and distributed recharge in data-scarce hard-rock regions. Journal of Hydro-Environment Research 9(4):554-568. http://dx.doi.org/10.1016\%2Fj.jher.2014.07.004

Mariotti G, Fagherazzi S, Wiberg PL, McGlathery KJ, Carniello L, Defina A (2010) Influence of storm surges and sea level on shallow tidal basin erosive processes. J. Geophys. Res. 115 C11012. https://doi.org/10.1029/2009JC005892

McHugh, M (2012) Interrater reliability: The kappa statistic. Biochemia Medica 22(3):276-282. https://doi.org/10.11613/bm.2012.031

Meskini-Vishkaee F, Davatgar N (2018) Evaluation of different predictor models for detailed soil particle-size distribution. Pedosphere 28(1):157-164. https://doi.org/10.1016/S1002-0160(17)60422-3

Mitchell M, Herman J, Bilkovic DM, Hershner C (2017) Marsh persistence under sea-level rise is controlled by multiple, geologically variable stressors. Ecosystem Health and Sustainability 3(10), 1379888. https://doi.org/10.1080/20964129.2017.1396009

Mitsch WJ, Gosselink JG (2007) Wetlands. 4th edn. John Wiley \& Sons.

Moerman E (2011) Long-term morphological modelling of the Mouth of the Columbia River. Master Thesis in Coastal Engineering. Civil Engineering and Geosciences. Delft University of Technology. Netherlands.

Mogensen LA, Rogers K (2018) Validation and comparison of a model of the effect of sea-level rise on coastal wetlands. Scientific Reports 8:1369.

Moore KA, Silberhorn GM (1980) James City County Tidal Marsh Inventory. Special Reports in Applied Marine Science and Ocean Engineering No. 188. Virginia Institute of Marine Science, College of William and Mary. https://doi.org/10.21220/V54H8T

Moore KA, Silberhorn GM (1976) Gloucester County Tidal Marsh Inventory. Special Report in Applied Marine Science and Ocean Engineering No. 64. Virginia Institute of Marine Science, College of William and Mary. https://doi.org/10.21220/V5972B.

Morgan PA, Burdick DM, Short FT (2009) The functions and values of fringing salt marshes in Northern New England, USA. Estuaries and Coasts 32:483-495. http://www.jstor.org/stable/40663558

Moriasi D, Arnold J, Van Liew M, Bingner R, Harmel D, Veith T (2007) Model evaluation guidelines for systematic quantification of accuracy in watershed simulations. Transactions of the American Society of Agricultural and Biological Engineers 50(3):885-900. https://doi.org/ 10.13031/2013.23153

Morris JT, Barber DC, Callaway JC, Chambers R, Hagen SC, Hopkinson CS, Johnson BJ, Megonigal P, Neubauer SC, Troxler T, Wigand C (2016) Contributions of organic and inorganic matter to sediment volume and accretion in tidal wetlands at steady state. Earth's Future 4(4):110-121. https://doi.org/10.1002/2015EF000334 
Morris JT, Sundareshwar PV, Nietch CT, Kjerfve B, Cahoon DR (2002) Responses of Coastal Wetlands to Rising Sea Level. Ecology 83(10):2869-2877. https://doi.org/ 10.1890/00129658(2002)083[2869:ROCWTR]2.0.CO;2

Neubauer S, Anderson IC, Constantine JA, Kuehl SA (2002) Sediment deposition and accretion in a mid-Atlantic (U.S.A.) tidal freshwater marsh. Estuarine Coastal and Shelf Science 54:713-727. https://doi.org/10.1006/ecss.2001.0854

NOAA Tides and Currents (2018) Relative Sea Level Trend 8638610 Sewells Point, Virginia. https://tidesandcurrents.noaa.gov/sltrends/sltrends_station.shtml?id=8638610. Accessed 11 November 2018.

NTHMP (2012) Proceedings and results of the 2011 NTHMP model benchmarking workshop. Boulder: US Department of Commerce/NOAA/NTHMP, NOAA Special Report 436p.

Odink SJ (2019) Long-term marsh growth and retreat in an online coupled hydrodynamic, morphodynamic and ecological model. Master Thesis In Water Engineering And Management. Faculty Of Engineering Technology. University Of Twente. The Netherlands.

Pinto L, Fortunato AB, Zhang Y, Oliveira A, Sancho FEP (2012) Development and validation of a three-dimensional morphodynamic modelling system for non-cohesive sediments. Ocean Model 57 58:1-14. https://doi.org/10.1016/j.ocemod.2012.08.005

Poppe LJ, Eliason AH, Fredericks JJ, Rendigs RR, Blackwood D, Polloni CF (2003) Grain-Size Analysis of Marine Sediments: Methodology and Data Processing. In Open File Report 00-358, Chapter 1. U.S. Geological Survey. https://pubs.usgs.gov/of/2000/of00-358/text/chapter1.htm. Accessed 12 December 2018.

Rahman A (2015) Cliff Erosion of salt marshes: Experimental evaluation of the effect of vegetation characteristics and sediment properties on erodibility. Master's thesis in Water Engineering \& Management. University of Twente Enschede, The Netherlands.

Rahmstorf S, Box JE, Feulner G, Mann ME, Robinson A, Rutherford S, Schaffernicht EJ (2015) Exceptional twentieth-century slowdown in Atlantic Ocean overturning circulation. Nature Climate Change 5:475-480. https://doi.org/10.1038/nclimate2554

Raposa K, Ekberg MLC, Burdick D, Ernst NT, Adamowicz SC (2017) Elevation change and the vulnerability of Rhode Island (USA) salt marshes to sea-level. Regional Environmental Change 17:389-397. https://doi.org/10.1007/s10113-016-1020-5

Reed DJ (1995) The response of coastal marshes to sea-level rise: survival or submergence? Earth Surface Processes and Landforms 20:39-48. https://doi.org/10.1002/esp.3290200105

Renard KG, Foster GR, Weesies GA, Porter JP (1991) RUSLE: Revised universal soil loss equation. Journal of Soil and Water Conservation 46:30-33.

Rodrigues M, Oliveira A, Queiroga H, Fortunato AB, Zhang. MY (2009) Three-dimensional modeling of the lower trophic levels in the Ria de Aveiro (Portugal). Ecological Modelling 220(9-10):12741290. 
Roelvink DJA, Reniers AJH (2011) A Guide to Modeling Coastal Morphology. World Scientific Publishing Company. Series: Advances in Coastal and Ocean Engineering. Book 12.

Roelvink DJA (2006) Coastal morphodynamic evolution techniques. Coastal Engineering 53(23):277-287.

Roland A, Zhang YJ, Wang HV, Meng Y, Teng YC, Maderich V, Brovchenko I, Dutour-Sikiric M, Zanke U (2012) A fully coupled 3D wave-current interaction model on unstructured grids. Journal of Geophysical Research 177:1-18. https://doi.org/10.1029/2012JC007952

Roland A (2009) Development of WWM II: Spectral wave modeling on unstructured meshes. Ph.D. thesis, Technical University Darmstadt, Institute of Hyraulic and Water Resources Engineering.

Sallenger AH, Doran KS, Howd PA (2012) Hotspot of accelerated sea-level rise on the Atlantic coast of North America. Nature Climate Change 2:884-888. https://doi.org/10.1038/nclimate1597

Santisteban JI, Mediavilla R, López-Pamo E, Dabrio CJ, Zapata MBR, García MJG, Castaño S, Martínez-Alfaro PE (2004) Loss on ignition: a qualitative or quantitative method for organic matter and carbonate mineral content in sediments? Journal of Paleolimnology 32: 287-299.

Schwimmer RA (2001) Rates and processes of marsh shoreline erosion in Rehoboth Bay, Delaware, USA. Journal of Coastal Research 17(3): 672-683.

Shepard CC, Crain CM, Beck MW (2011) The protective role of coastal marshes: A systematic review and meta-analysis. PloS ONE 6:e27374. https://doi.org/10.1371/journal.pone.0027374

Silinski, A, Heuner M, Schoelynck J, Puijalon S, Schröder U, Fuchs E et al. (2015) Effects of wind waves versus ship waves on tidal marsh plants: a flume study on different life stages of Scirpus maritimus. PLoS ONE, https://doi.org/10.1371/journal.pone.0118687

Singh J, Knapp V, Demissie M (2004) Hydrologic modeling of the Iroquois River watershed using HSPF and SWAT. ISWS Contract Report CR 2004-08. Illinois State Water Survey. http://www.isws.illinois.edu/pubdoc/CR/ISWSCR2004-08.pdf. Accessed 22 November 2019.

Sisson GM, Shen J, Kim SC, Boon JD, Kuo AY (1997) VIMS three dimensional hydrodynamiceutrophication model (HEM-3D): Application of the hydrodynamic model to the York River system. SRAMSOE Report No. 341. Virginia Institute of Marine Science. Gloucester Point, Va. 123pp. https://doi.org/10.21220/V5ZB3N

Stanev EV, Pein JU, Grashorn S, Zhang Y, Schrum C (2018) Dynamics of the Baltic Sea Straits via Numerical Simulation of Exchange Flows. Ocean Modelling 131:40-58. https://doi.org/10.1016/j.ocemod.2018.08.009

Stanev EV, Grashorn S, Zhang YJ (2017) Cascading ocean basins: numerical simulations of the circulation and interbasin exchange in the Azov-Black-Marmara-Mediterranean Seas system. Ocean Dynamics 67:1-23. https://doi.org/10.1007/s10236-017-1071-2 
1048

1049

1050

1051

1052

1053

1054

1055

1056

1057

1058

1059

1060

1061

1062

1063

1064

1065

1066

1067

1068

1069

1070

1071

1072

1073

1074

1075

1076

1077

1078

1079

1080

1081

1082

1083

1084

1085

1086

1087

1088

1089

1090

1091

1092

1093

1094

1095
Styles R, Brown ME, Brutsché KE, Li H, Beck TM, Sánchez A (2016) Long-term morphological modeling of barrier island tidal inlets. Journal of Marine Science and Engineering 4(65):126-148. https://doi.org/10.3390/jmse4040065

Tang W, Hu J, Zhang H, Wu P, He H (2015) Kappa coefficient: A popular measure of rater agreement. Shanghai Archives of Psychiatry 27(1):62-67.

Temmerman S, Goers G, Wartel S, Meire P (2003b) Spatial and temporal factors controlling shortterm sedimentation in a salt and freshwater tidal marsh, Scheldt Estuary, Belgium, SW Netherlands, Earth Surf. Processes Landforms 28:739-755, https://doi.org/10.1002/esp.495

Titus JG, Anderson KE, Cahoon DR, Gesch DB, Gill SK, Gutierrez BT, Thieler ER, William SJ (2009) Coastal Sensitivity to Sea-Level Rise: A Focus on the Mid-Atlantic Region. U.S. Climate Change Science Program and the Subcommittee on Global Change Research. Washington, D.C.

Tobias CR, Harvey JW, Anderson IC (2001) Quantifying groundwater discharge through fringing wetlands to estuaries: Seasonal variability, methods comparison, and implications for wetland-estuary exchange. Limnology and Oceanography 46 (3):604-615. https://doi.org/10.4319/lo.2001.46.3.0604

Umlauf L, Burchard H (2003) A generic length-scale equation for geophysical turbulence models. Journal Marine Research 6: 235-265. https://doi.org/10.1357/002224003322005087

USGS (United States Geological Survey) (2011) Bare Earth DEM VA_FEMA_MiddleCounties_2011, multiple tiles. U.S. Geological Survey. Access through

https://vgin.maps.arcgis.com/home/index.html. Accessed 9 January 2017.

Van Proosdij D, Davidson-Arnott RGD, Ollerhead J (2006) Controls on spatial patterns of sediment deposition across a macro-tidal salt marsh surface over single tidal cycles. Estuarine Coastal Shelf Sci. 69:64-86. https://doi.org/10.1016/j.ecss.2006.04.022

Walters D, Moore LJ, Durán O, Fagherazzi S, Mariotti G (2014) Interactions between barrier islands and backbarrier marshes affect island system response to sea level rise: Insights from a coupled model. J. Geophys. Res. 119:2013-2031

Warner JC, Sherwood CR, Signell RP, Harris CK, Arango HG (2008) Development of a threedimensional, regional, coupled wave, current, and sediment-transport model. Computers \& Geosciences 34: 1284-1306. https://doi.org/10.1016/j.cageo.2008.02.012

Viera AJ, Garrett JM (2005) Understanding inter observer agreement: The kappa statistic. Family Medicine 37(5): 360-363.

Willmott CJ, Robeson SM, Matsuura K, Ficklin DL (2015) Assessment of three dimensionless measures of model performance. Environmental Modelling and Software 73:167-174. https://doi.org/10.1016/j.envsoft.2015.08.012

Willmott CJ, Robeson SM, Matsuura K, Ficklin DL (2012) Short Communication: A refined index of model performance. International Journal of Climatology 32:2088-2094.

https://doi.org/10.1002/joc.2419 
Willmott CJ (1982) Some comments on the evaluation of model performance. Bulletin of the American Meteorological Society 63:1309-1313. https://doi.org/10.1175/15200477(1982)063\%3C1309:SCOTEO\%3E2.0.CO;2.

Ye F, Zhang YJ, Wang H, Friedrichs MA, Irby ID, Alteljevich E, Valle-Levinson A, Wang Z, Huang H, Shen J, Du J (2018) A 3D unstructured-grid model for Chesapeake Bay: importance of bathymetry. Ocean Modelling 127:16-39. https://doi.org/10.1016/j.ocemod.2018.05.002

Ye F, Chen Q, Blanckaert K, Ma J (2013) Riparian vegetation dynamics: Insight provided by a process-based model, a statistical model and field data. Ecohydrology 6:567-85. https://doi.org/10.1002/eco.1348

Yu HC, Zhang YJ, Yu JCS, Terng C, Sun W, Ye F, Wang HV, Wang Z, Huang H (2017) Simulating multi-scale oceanic processes around Taiwan on unstructured grids. Ocean Modelling 112:7293. http://doi.org/10.1016/j.ocemod.2017.09.007

Zhang Y, Gerdts N, Ateljevich E, and Nam K (2019) Simulating vegetation effects on flows in 3D using an unstructured grid model: model development and validation. Ocean Dynamics https://doi.org/10.1007/s10236-019-01333-8

Zhang, YJ, Ye F, Staney EV, Grashorn S (2016) Seamless cross-scale modeling with SCHISM. Ocean Modelling 102:64-81. https://doi.org/10.1016/j.ocemod.2016.05.002

Zhang YJ, Ateljevich E, Yu HC, Wu CH, Yu JCS (2015) A new vertical coordinate system for a 3D unstructured-grid model. Ocean Modelling 85:16-31. https://doi.org/10.1016/j.ocemod.2014.10.003

Zhang YJ, Baptista AM (2008) SELFE: A semi-implicit Eulerian-Lagrangian finite-element model for cross-scale ocean circulation. Ocean Modelling 21(3-4):71-96.

https://doi.org/10.1016/j.ocemod.2007.11.005 


$$
\text { Momentum equation: } \frac{D \mathbf{u}}{D t}=\frac{\partial}{\partial z}\left(v \frac{\partial \mathbf{u}}{\partial z}\right)-g \nabla \eta+\mathbf{F}
$$

$\nabla \cdot \mathbf{u}+\frac{\partial w}{\partial z}=0$

$\frac{\partial \eta}{\partial t}+\nabla \cdot \int_{-h}^{\eta} \mathbf{u} d z=0$

Transport equation:

Equation of state:

$$
\rho=\rho(S, T, p)
$$

where

$$
\nabla\left(\frac{\partial}{\partial x}, \frac{\partial}{\partial y}\right)
$$

$$
D / D t \quad \text { material derivative }\left(\mathrm{s}^{-1}\right)
$$$$
(x, y) \quad \text { horizontal Cartesian coordinates }(\mathrm{m})
$$$$
z \quad \text { vertical coordinate, positive upward (m) }
$$$$
t \quad \text { time (s) }
$$$$
\eta(x, y, t) \quad \text { free-surface elevation (m) }
$$$$
h(x, y) \quad \text { bathymetric depth }(\mathrm{m})
$$$$
\mathbf{u}(x, y, z, t) \text { horizontal velocity, with Cartesian components }(u, v)
$$$$
w \quad \text { vertical velocity }
$$

$\boldsymbol{F} \quad$ other forcing terms in momentum (baroclinic gradient $\left(-\frac{g}{\rho_{0}} \int_{z}^{\eta} \nabla \rho d \zeta\right)$, horizontal viscosity, Coriolis, earth tidal potential, atmospheric pressure, radiation stress) $g \quad$ acceleration of gravity, in $\left(\mathrm{ms}^{-2}\right)$

C tracer concentration (e.g., salinity, temperature, sediment, etc.)

$v \quad$ vertical eddy viscosity, in $\left(\mathrm{m}^{2} \mathrm{~s}^{-1}\right)$

$\kappa \quad$ vertical eddy diffusivity, for tracers, in $\left(\mathrm{m}^{2} \mathrm{~s}^{-1}\right)$

$F_{h} \quad$ horizontal diffusion and mass sources/sinks

As previously stated, a simpler 2D barotropic configuration was used in this study. 


\section{Appendix B - TMM Numerical Formulation: Geometry and Discretization}

SCHISM-TMM is a finite-element model that uses a flexible unstructured grid (UG). For the

1173

1174

1175

1176

1177

1178

1179

1180

1181

1182

1183

1184

1185

1186

1187

1188

1189

1190

1191

1192

1193

1194 horizontal grid, hybrid triangular-quadrangular (quads) elements are employed to take advantage of the superior boundary-fitting capability of triangles as well as efficiency/accuracy of quads in representing certain features (e.g., channels) as needed.

The basic 3D computational unit in SCHISM is a triangular prism (Figure 13) or quad prism.

Surface elevations $(\eta)$ are defined at the nodes, and the horizontal velocities $(u, v)$ are defined at the side centers and whole levels. The vertical velocity (w) is defined at the element centers and whole levels, and the tracer concentration (C) is defined at prism center, as it is solved with a finite volume method. The conformal and non-conformal linear shape functions (Le Roux 2012) are used for elevations and velocities respectively.

Boundary Conditions. The differential equations previously described require initial conditions (I.C.) and boundary conditions (B.C.). Generally, all state variables $(\eta, \mathrm{u}, \mathrm{C})$ are specified at $\mathrm{t}=0$ as I.C. In addition, some variables are specified at all open lateral boundary segments (e.g. open ocean, rivers, etc.). At the sea-surface interface, SCHISM enforces the balance between the internal Reynolds stress and the applied shear stress:

$$
v \partial \boldsymbol{u} \partial z=\boldsymbol{\tau}_{w}, \quad z=\eta
$$

Since the bottom boundary layer is typically not well resolved in ocean models, the no-slip condition at the sea or river bottom $(\mathrm{u}=\mathrm{w}=0)$ is replaced by a balance between the internal Reynolds stress and the bottom frictional stress,

$$
v \partial \boldsymbol{u} \partial z=\boldsymbol{\tau}_{b}, \text { at } z=-h .
$$

For a turbulent boundary layer, the bottom stress is defined as:

$$
\boldsymbol{\tau}_{b}=C_{D}\left|\boldsymbol{u}_{b}\right| \boldsymbol{u}_{b}
$$

where $\boldsymbol{u}_{b}$ is the near bottom velocity. 
1196 be supplemented by turbulence closure equations for the viscosity/diffusivity. SCHISM uses the 1197 Generic Length-Scale (GLS) model of Umlauf and Burchard (2003) with proper I.C. and B.C. for each 1198 differential equation.

1199

1200

1201

1202

1203

1204

1205

1206

1207

1208

1209

1210

1211

1212

1213

1214

1215

1216

1217

1218

1219

1220

1221

1222

1223

1224

1225

1226

1227

1228

1229

1230

\section{Appendix C. Main Equations for Supporting Models}

Suspended Sediment Transport. Suspended sediment concentrations are computed as follows

(Pinto et al. 2012):

$$
\frac{\partial c_{j}}{\partial t}+\nabla_{h} \cdot\left(\boldsymbol{u} c_{j}\right)+\frac{\partial\left[\left(w-w_{s j}\right) c_{j}\right]}{\partial z}=\frac{\partial}{\partial z}\left(\kappa \frac{\partial c_{j}}{\partial z}\right)+F_{h}
$$

$c_{j}$ - volume concentration of suspended sediment in class $j$

$\boldsymbol{u}$ - horizontal velocity

$\kappa$ - eddy diffusivity

$w_{s j}$ - settling velocity

$F_{h}$ - horizontal mixing

Spectral Wave Model (WWM-III). Governing equation for wave action is defined as (Ronald et al. 2012):

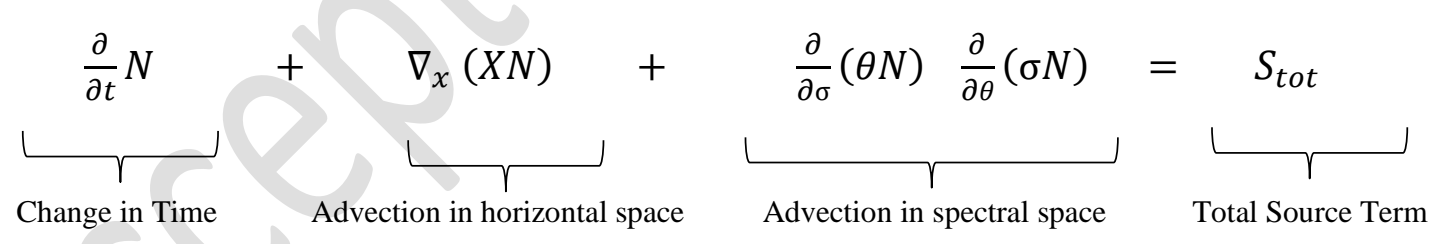

Where:

$N_{(t, X, \sigma, \theta)}=\frac{E_{(t, X, \sigma, \theta)}}{\sigma}$

$\mathrm{E}=$ variance density of the sea level elevations

$\sigma=$ relative wave frequency

$\theta=$ wave direction

$\boldsymbol{X}=$ Cartesian coordinate vector $(\mathrm{x}, \mathrm{y})$ in the geographical space 


$$
K=\frac{N \sum_{i=1}^{k} x_{i i}-\sum_{i-1}^{k}\left(x_{1+} X x_{+1}\right)}{N^{2}-\sum_{i=1}^{k}\left(x_{i+} X x_{+1}\right)}
$$

Mean Absolute Error (MAE)

$$
\mathrm{MAE}=\frac{1}{n} \sum_{\mathrm{i}=1}^{\mathrm{n}}\left|P_{i}-O_{i}\right|
$$

Willmott Modified Index of Agreement (dr)

$$
d_{r}=\left\{\begin{array}{c}
1-\frac{\sum_{\mathrm{i}=1}^{\mathrm{n}}\left|P_{i}-O_{i}\right|}{c \sum_{\mathrm{i}=1}^{\mathrm{n}}\left|O_{i}-\bar{O}\right|}, \text { when } \\
\sum_{i=0}^{n}\left|P_{i}-O_{i}\right| \leq c \sum_{i=0}^{n}\left|O_{i}-\bar{O}\right| \\
\frac{c \sum_{\mathrm{i}=1}^{\mathrm{n}}\left|O_{i}-\bar{O}\right|}{\sum_{\mathrm{i}=1}^{\mathrm{n}}\left|P_{i}-O_{i}\right|}-1, \text { when } \\
\sum_{i=0}^{n}\left|P_{i}-O_{i}\right|>c \sum_{i=0}^{n}\left|O_{i}-\bar{O}\right| \\
\mathrm{c}=2
\end{array}\right.
$$

$\begin{gathered}\text { Nash_Sutcliffe Efficiency } \\ (\mathrm{NSE})\end{gathered} \quad \mathrm{NSE}=1-\frac{\sum_{i=1}^{n}\left(O_{i}-P_{i}\right)^{2}}{\sum_{i=1}^{n}\left(O_{i}-\bar{O}\right)^{2}}$

Observations Standard

Deviation Ratio (RSR)

$$
R S R=\frac{R M S E}{S T D E V_{o b s}}=\frac{\left[\sqrt{\sum_{i=1}^{n}\left(O_{i}-P_{i}\right)^{2}}\right]}{\left[\sqrt{\sum_{i=0}^{n}\left(O_{i}-\bar{O}\right)^{2}}\right]}
$$




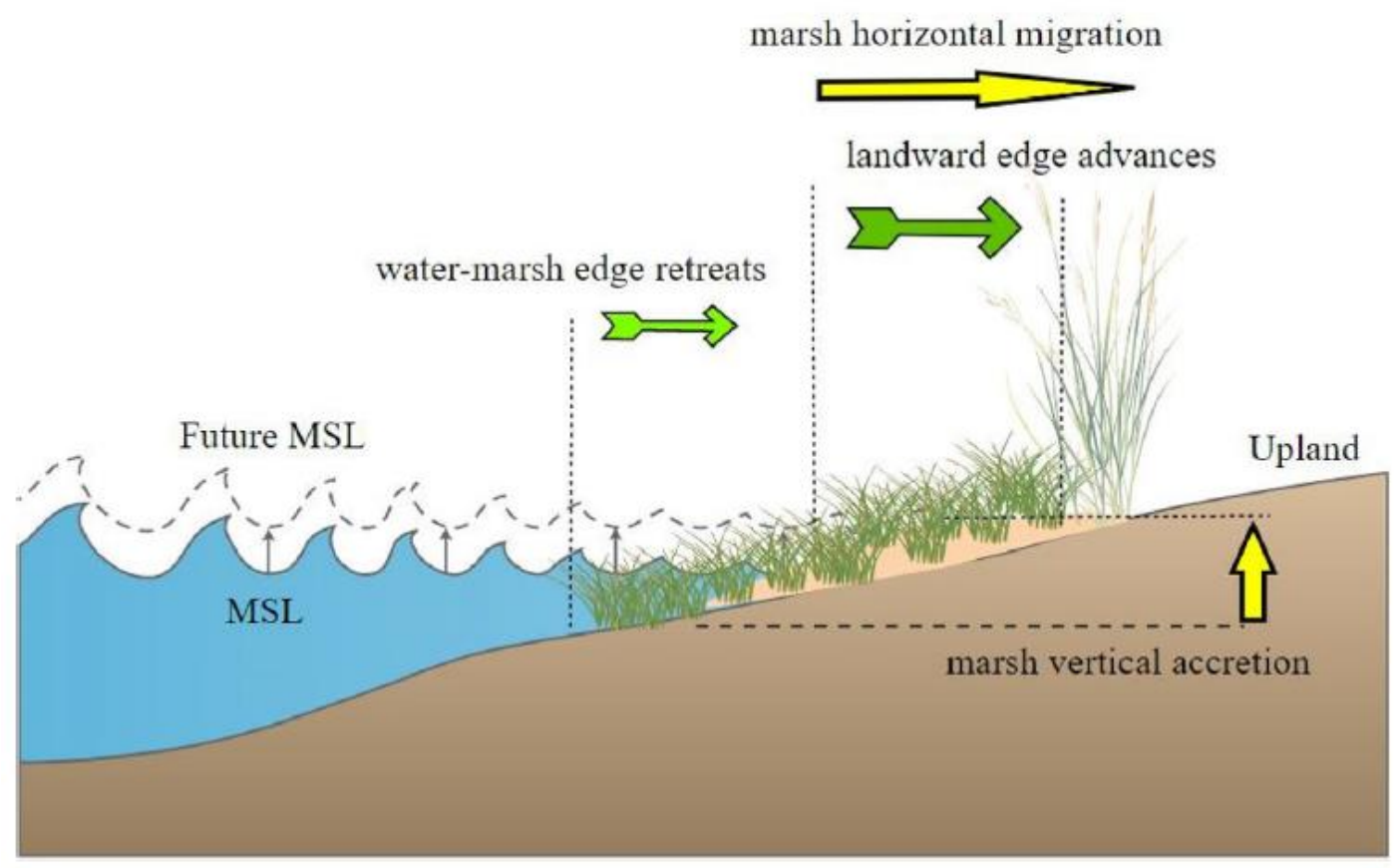

Fig. 1 Diagram of vertical and horizontal marsh responses to sea-level rise Symbols courtesy of the Integration and Application Network (ian.umces.edu/symbols/), University of Maryland Center for Environmental Science 


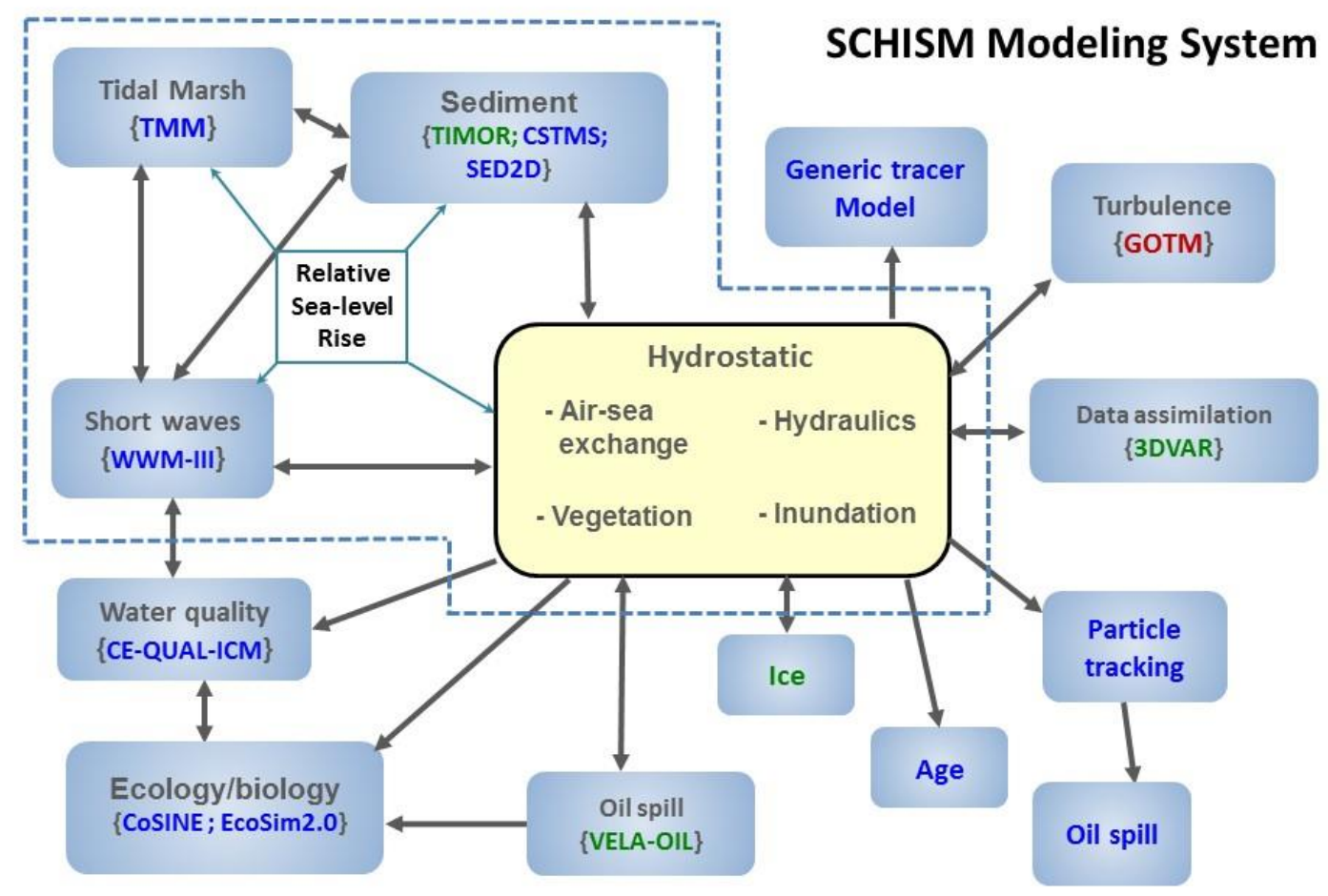

Status of models: Open-released / In-development / Free-from-web

\{model name\}/ $\square$ : Dynamic Core

Fig. 2 SCHISM modeling system. The dashed box indicates the TMM and key supporting components. The hydrostatic core serves as the pillar of the system to provide hydrodynamic variables to other models as well as to facilitate exchange of variables between models in a parallel software environment 

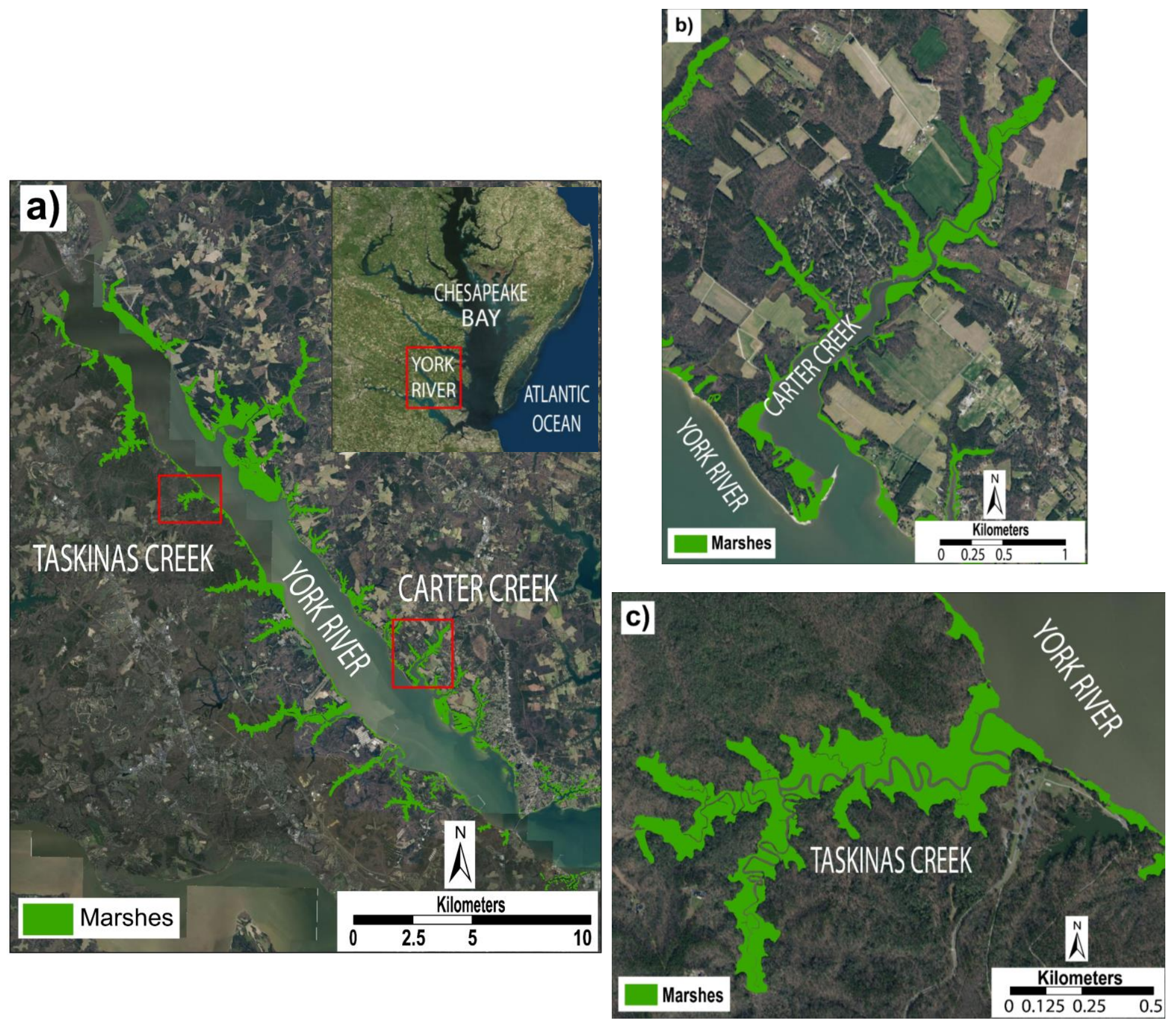

Fig. 3 a) York River system; b) Carter Creek and c) Taskinas Creek: study areas in the York River. Bright green areas represent tidal marshes. Background Image: VBMP2017/VBMP2017_ WGS Virginia Geographic Information Network (VGIN) 

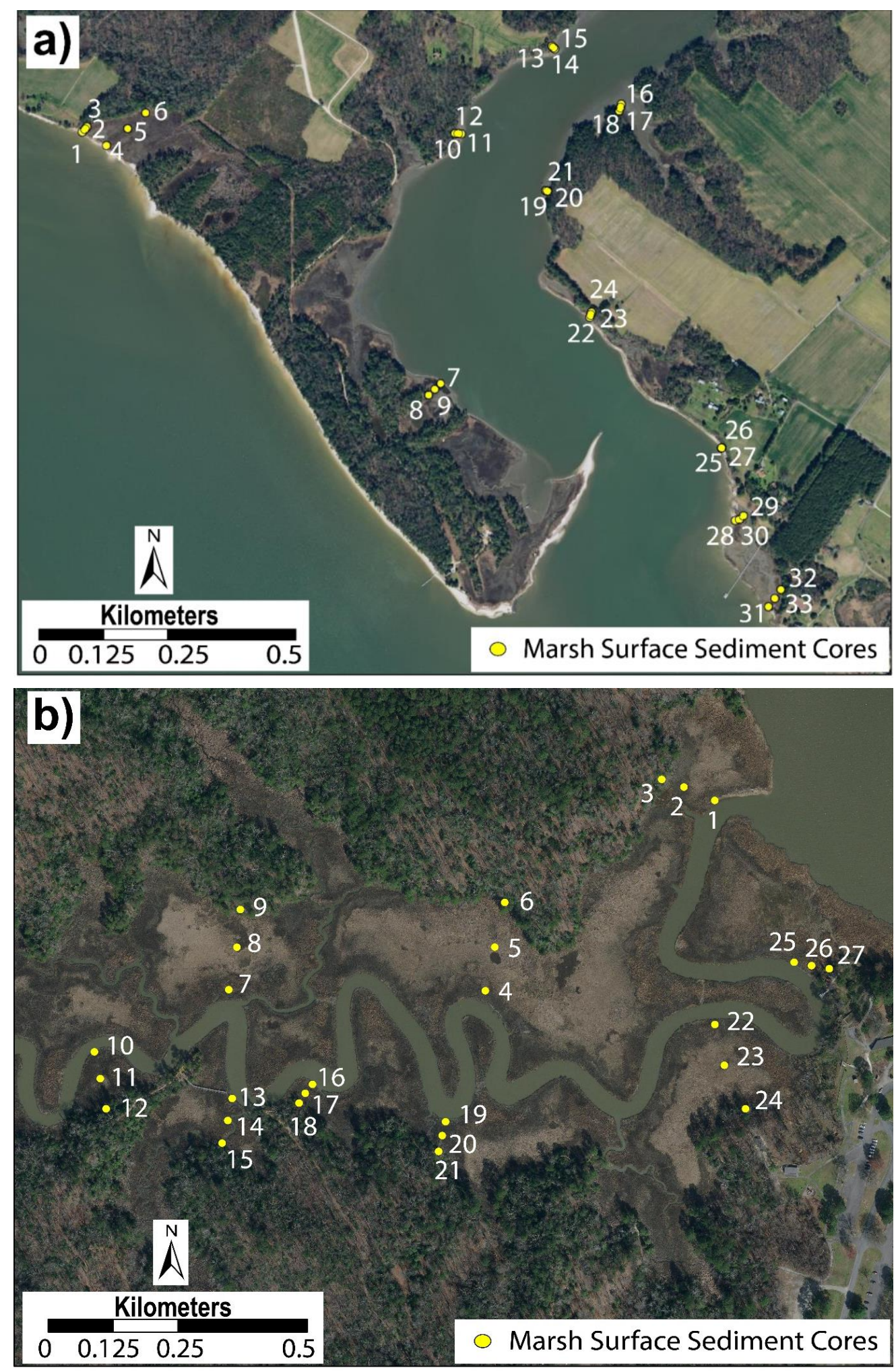

Fig. 4 Locations of marsh near surface (upper eight $\mathrm{cm}$ ) sediment cores sampled in a) Carter Creek (33 cores) and b) Taskinas Creek (27 cores). Background Image: VBMP2017/VBMP2017_WGS Virginia Geographic Information Network (VGIN) 

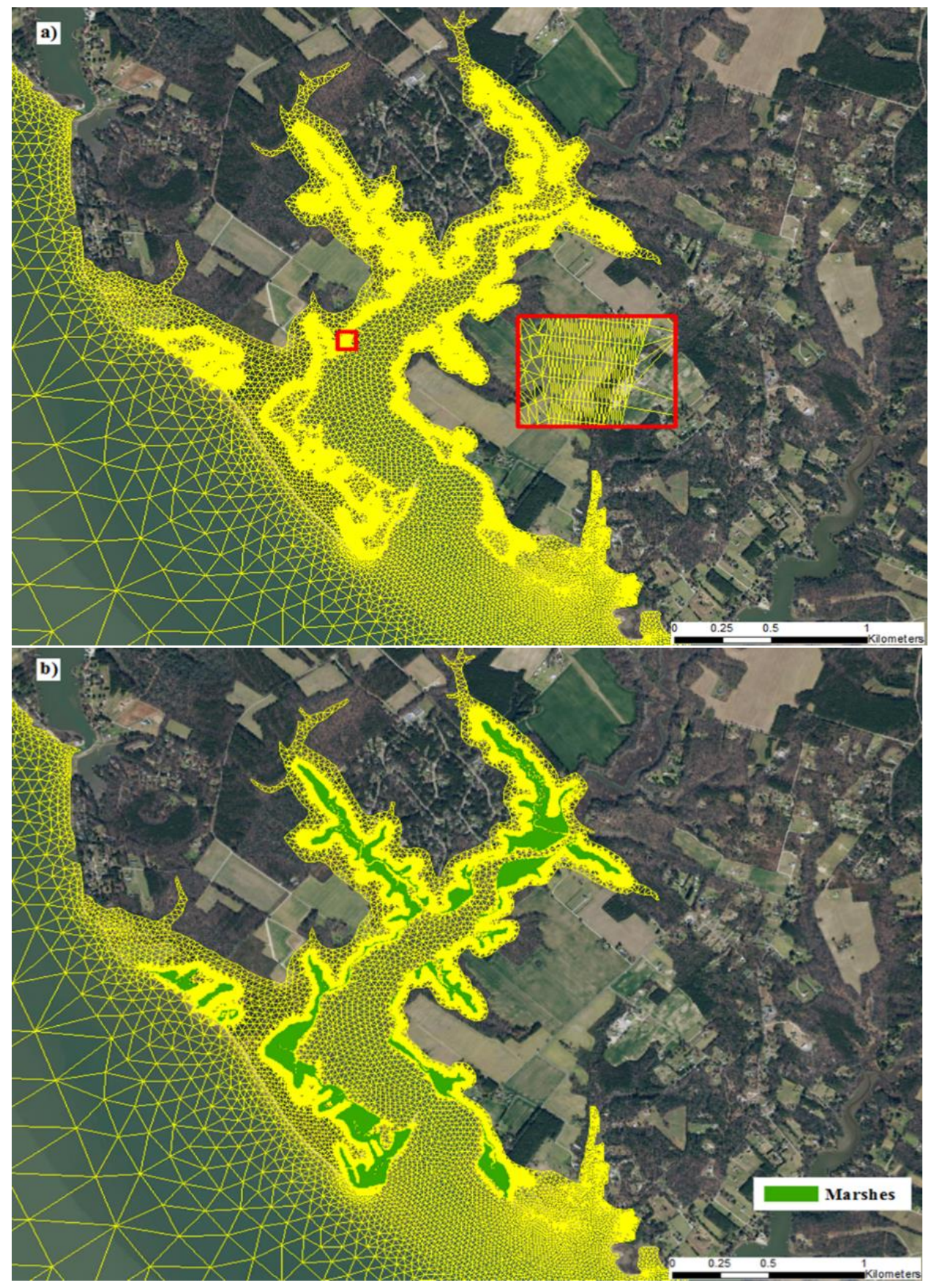

Fig. 5 a) Unstructured TMM grid used for Carter Creek marshes; b) The marsh layer (in green) is displayed on top of the grid (in yellow). Upland adjacent to the marsh is highly resolved to more accurately capture marsh transgression. Background Image: VBMP2017/VBMP2017_ WGS - Virginia Geographic Information Network (VGIN) 

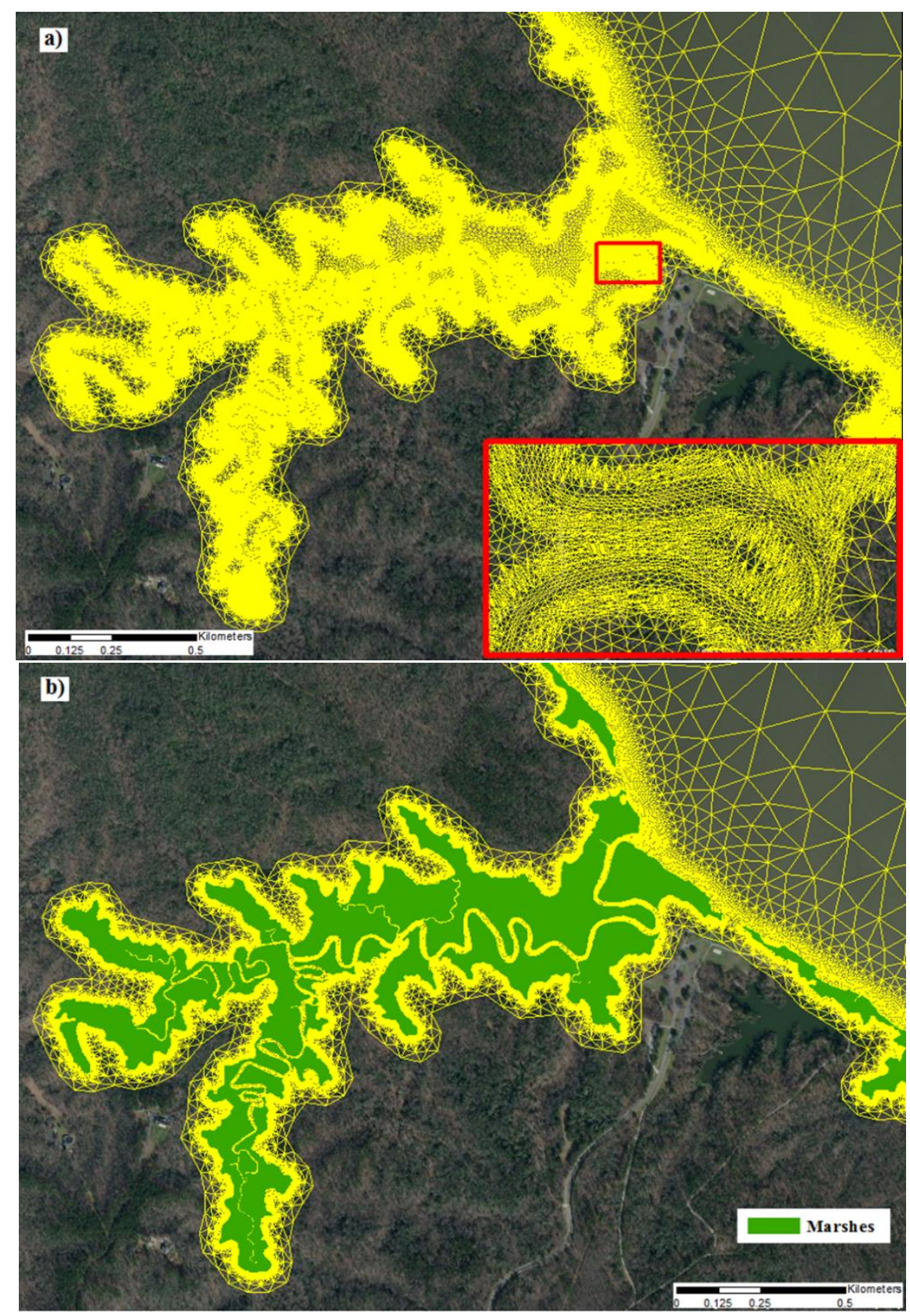

Fig. 6 a) Unstructured TMM grid used for Taskinas Creek marshes; b) The marsh layer (in green) is displayed on top of the grid (in yellow). Upland adjacent to the marsh is highly resolved to more accurately capture marsh transgression. Background Image: VBMP2017/VBMP2017_ WGS - Virginia Geographic Information Network (VGIN) 


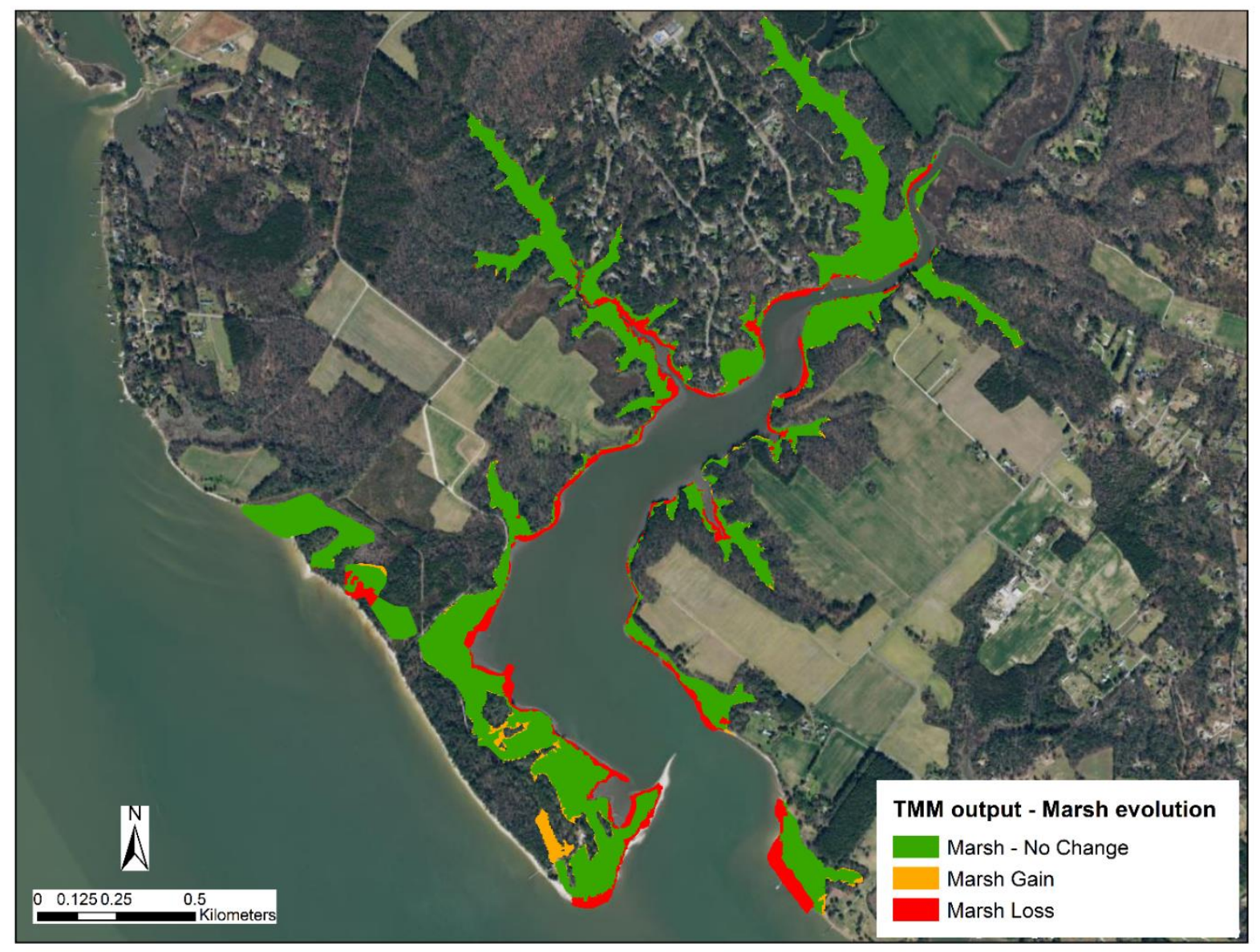

Fig. 7 Marsh boundary evolution output for Carter Creek - Hindcast outputs: changes in marsh boundary after 40 years of simulation with a sea-level rise of $4 \mathrm{~mm} / \mathrm{yr}$. Background image: VBMP2017/VBMP2017_WGS - Virginia Geographic Information Network (VGIN) 


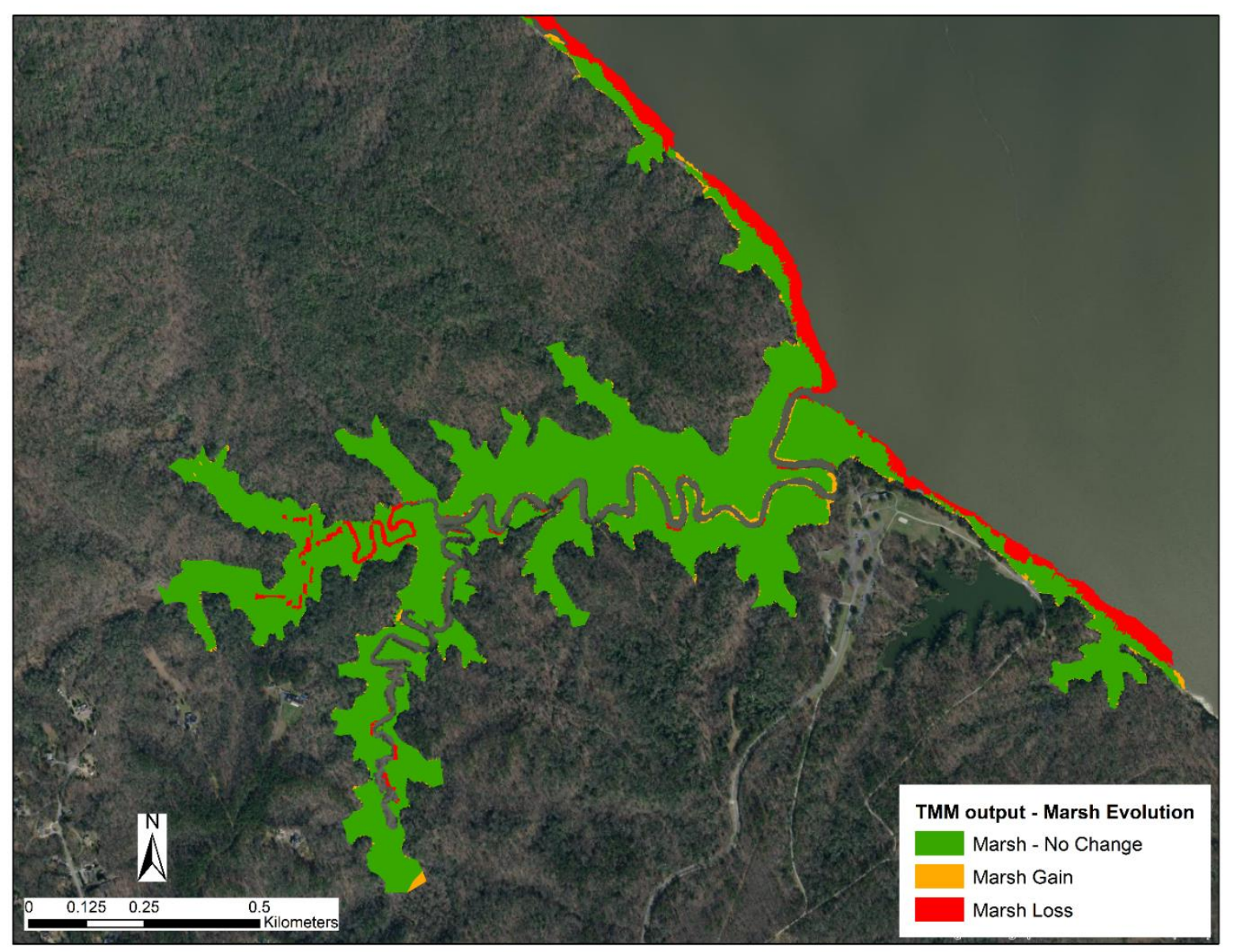

Fig. 8 Marsh boundary evolution output for Taskinas Creek - Hindcast outputs: changes in marsh boundary after 40 years of simulation with a sea-level rise of $4 \mathrm{~mm} / \mathrm{yr}$. Background image: VBMP2017/VBMP2017_WGS - Virginia Geographic Information Network (VGIN) 

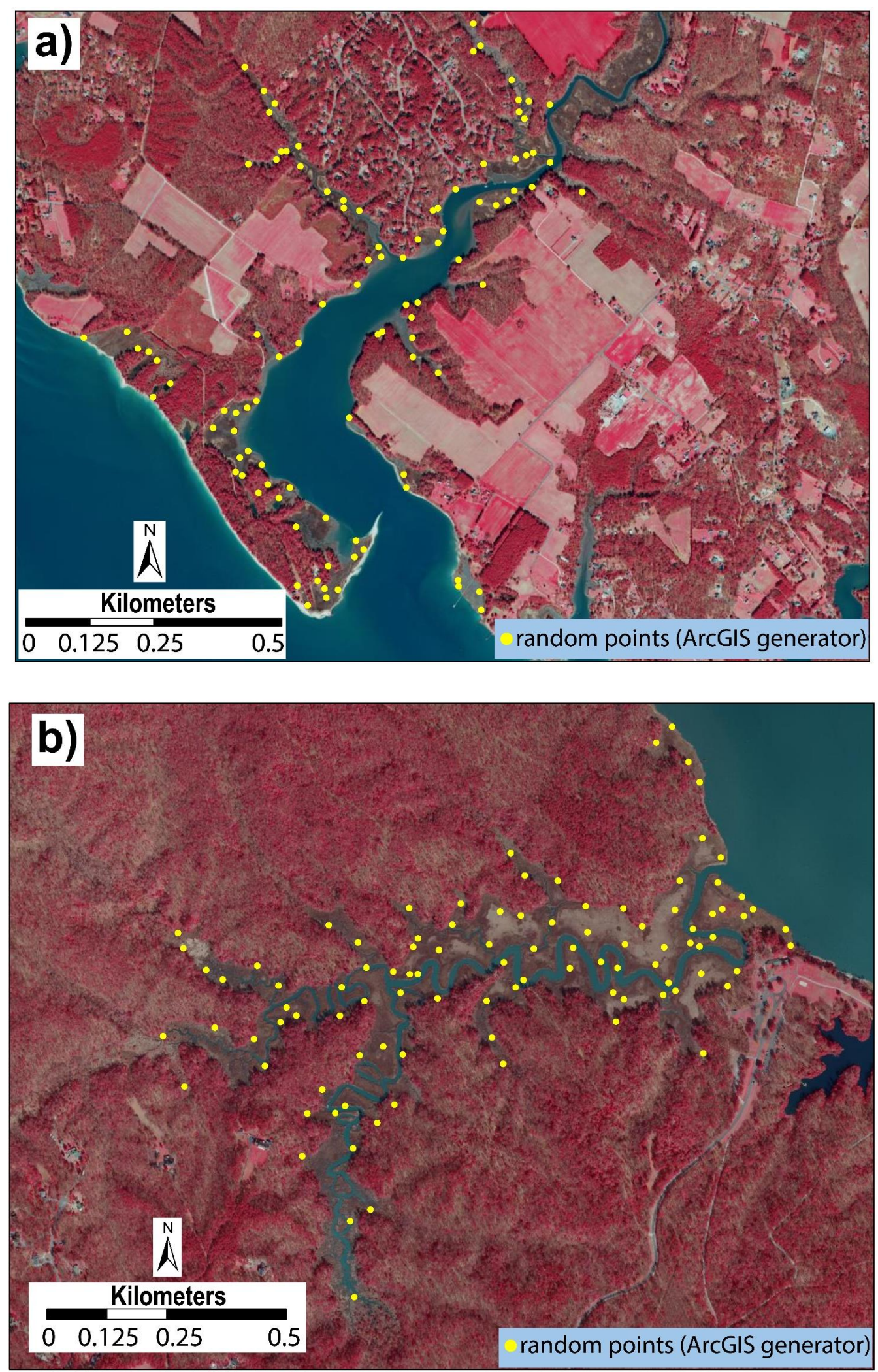

Fig. 9 Points used to generate the error matrices in a) Carter Creek (100 points) and Taskinas Creek (100 points). Points were generated using ArcGIS point generator. Background image: VBMP2017/VBMP2017_Infrared_WGS - Virginia Geographic Information Network (VGIN) 

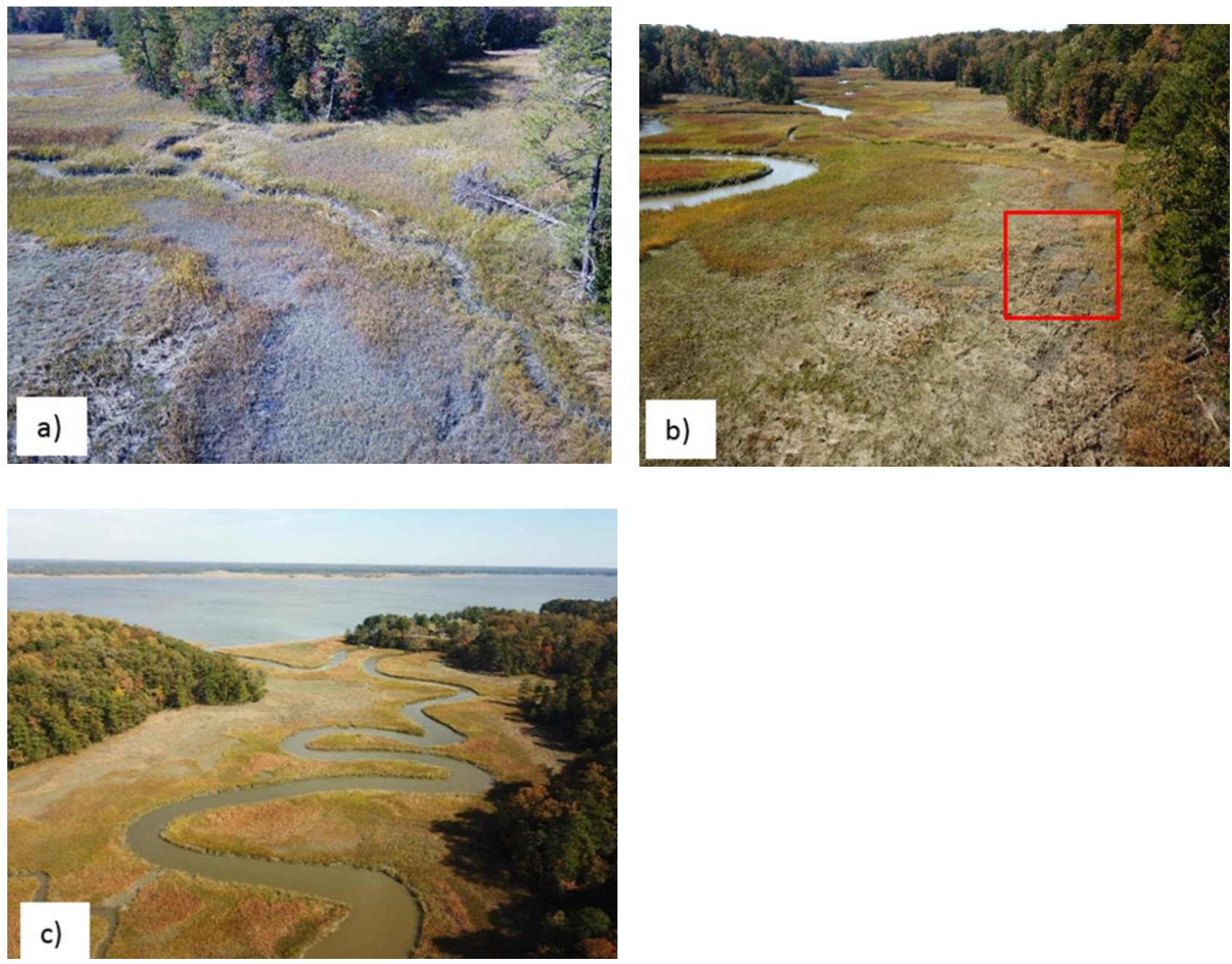

Fig. 10 Aerial drone photos of Taskinas Creek - a) it displays different soil conditions around marsh channels; b) localized depressions can be seen close to the upland edge (red box); c) it shows marsh areas affected by the presence of tree canopies 


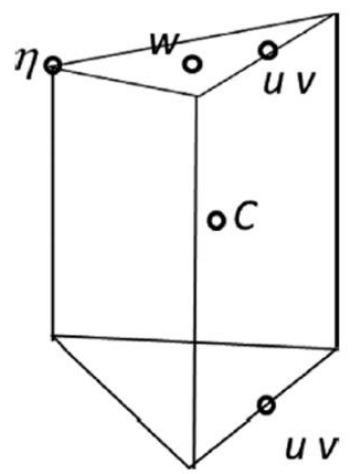

Fig. 11 Basic 3D computational unit (triangular element) in SCHISM. The elevation ( $\eta$ ) is defined at node (vertex) of a triangular element, horizontal velocity $(u, v)$ at side center and whole levels, vertical velocity $(w)$ at element centroid and whole level, and tracers $(C)$ at the prism center 